\title{
Deciphering the Role of Mucosal Immune Responses and the Cervicovaginal Microbiome in Resistance to HIV Infection in HIV-Exposed Seronegative (HESN) Women
}

\author{
(D) Sivasankaran Munusamy Ponnan, ${ }^{\text {ab }}$ Kannan Thiruvengadam, ${ }^{\text {a }}$ Chaitanya Tellapragada, ${ }^{c}$ Anoop T. Ambikan, ${ }^{c}$ Aswathy Narayanan, ${ }^{c}$ \\ Sujitha Kathirvel, ${ }^{a}$ Manikannan Mathayan, ${ }^{a}$ Janani Shankar, ${ }^{a}$ Akshaya Rajaraman, ${ }^{a}$ Mehar Afshan Amanulla, ${ }^{a}$

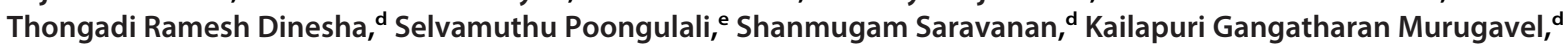 \\ Soumya Swaminathan, ${ }^{a}$ (D) Vijayakumar Velu, ${ }^{\text {,g }}$ Barbara Shacklett, ${ }^{\text {h }}$ (D) Ujjwal Neogi, ${ }^{c, i}$ Luke Elizabeth Hanna ${ }^{\text {** }}$ \\ aNational Institute for Research in Tuberculosis (Indian Council of Medical Research), Chennai, India \\ bCentre for Infectious Disease Research, Indian Institute of Science (IISC), Bangalore, India \\ 'Division of Clinical Microbiology, Karolinska Institute, Stockholm, Sweden \\ dYRG Center for AIDS Research and Education, Chennai, India \\ eCART CRS, Infectious Diseases Medical Center, VHS, Chennai, India \\ fDivision of Microbiology and Immunology, Emory Vaccine Center, Yerkes National Primate Research Center, Emory University, Atlanta, Georgia, USA \\ פDepartment of Pathology and Laboratory Medicine, Emory School of Medicine, Emory University, Atlanta, Georgia, USA \\ nDepartment of Medical Microbiology and Immunology, School of Medicine, University of California, Davis, California, USA \\ 'Manipal Institute of Virology (MIV), Manipal Academy of Higher Education, Manipal, Karnataka, India
}

ABSTRACT The female genital tract (FGT) is an important site of human immunodeficiency virus (HIV) infection. Discerning the nature of HIV-specific local immune responses is crucial for identifying correlates of protection in HIV-exposed seronegative (HESN) individuals. The present study involved a comprehensive analysis of soluble immune mediators, secretory immunoglobulins (slg), natural killer (NK) cells, $\mathrm{CXCR5}^{+} \mathrm{CD}^{+} \mathrm{T}$ cells, $\mathrm{T}$ follicular helper (Tfh) cells, and T regulatory cells (Tregs) in the vaginal mucosa as well as the nature and composition of the cervicovaginal microbiome in HESN women. We found significantly elevated antiviral cytokines, soluble immunoglobulins, and increased frequencies of activated NK cells, CXCR5 ${ }^{+} \mathrm{CD}^{+}{ }^{+} \mathrm{T}$ cells, and Tfh cells in HESN females compared to HIV-unexposed healthy (UH) women. Analysis of the genital microbiome of HESN women revealed a greater bacterial diversity and increased abundance of Gardnerella spp. in the mucosa. The findings suggest that the female genital tract of HESN females represents a microenvironment equipped with innate immune factors, antiviral mediators, and critical T cell subsets that protect against HIV infection.

IMPORTANCE The vast majority of human immunodeficiency virus (HIV) infections across the world occur via the sexual route. The genital tract mucosa is thus the primary site of HIV replication, and discerning the nature of HIV-specific immune responses in this compartment is crucial. The role of the innate immune system at the mucosal level in exposed seronegative individuals and other HIV controllers remains largely unexplored. This understanding can provide valuable insights to improve vaccine design. We investigated mucosal T follicular helper (Tfh) cells, $\mathrm{CXCR5}^{+} \mathrm{CD}^{+} \mathrm{T}$ cells, natural killer (NK) cells subsets, soluble immune markers, and microbiome diversity in HIV-exposed seronegative (HESN) women. We found a significantly higher level of mucosal CXCR5 ${ }^{+} \mathrm{CD} 8^{+} \mathrm{T}$ cells, $\mathrm{CD} 4^{+}$ Tfh cells, activated NK cell subsets, and antiviral immune cell mediators in HESN women. We also found a higher abundance of Gardnerella spp., microbiome dysbiosis, and decreased levels of inflammatory markers to be associated with reduced susceptibility to HIV infection. Our findings indicate that increased distribution of mucosal NK cells, CXCR5 ${ }^{+}$ $\mathrm{CD}^{+} \mathrm{T}$ cells, Th cells, and soluble markers in HIV controllers with a highly diverse cervicovaginal microbiome could contribute effectively to protection against HIV infection. Overall,

Citation Munusamy Ponnan S, Thiruvengadam K, Tellapragada C, Ambikan AT, Narayanan A, Kathirvel S, Mathayan M, Shankar J, Rajaraman A, Afshan Amanulla M, Dinesha TR, Poongulali S, Saravanan S, Murugavel KG, Swaminathan S, Velu V, Shacklett B, Neogi U, Hanna LE. 2021. Deciphering the role of mucosal immune responses and the cervicovaginal microbiome in resistance to HIV infection in HIV-exposed seronegative (HESN) women. Microbiol Spectr 9:e00470-21. https://doi.org/10.1128/Spectrum .00470-21.

Editor Miguel Angel Martinez, Fundacio irsiCaixa

Copyright $\odot 2021$ Munusamy Ponnan et al. This is an open-access article distributed under the terms of the Creative Commons Attribution 4.0 International license.

Address correspondence to Luke Elizabeth Hanna, hanna@nirt.res.in.

* Present address: Luke Elizabeth Hanna, Department of HIV/AIDS, National Institute for Research in Tuberculosis, Chennai, India.

Received 14 June 2021

Accepted 23 July 2021

Published 27 October 2021 
our findings imply that future vaccine design should emphasize inducing these highly functional cell types at the mucosal sites.

KEYWORDS cytobrush, cervicovaginal lavage, HESN, NK cells, TSCM cells, Tfh cells, $\mathrm{CXCR}^{+}{ }^{+} \mathrm{CD} 8^{+}$cells, B cells, CBA, cervicovaginal microbiota, memory B cells

ucosal surfaces are primarily protected by innate immune mechanisms, but adaptive immune mechanisms also operate (1). The natural barriers present in the female genital tract (FGT) are insufficient to protect against all infections, although the FGT is a site of immunological balance (2). Innate immune cells play a vital role in the nonspecific destruction of foreign organisms. Natural killer (NK) cells recognize infected host cells via surface receptors and use various mechanisms to kill them (3). Increased NK cell activity is reflected by the higher cytotoxic capacity of NK cells and increased production of NK cell-specific cytokines and chemokines associated with control of infection (4-6). Perturbations in the NK cell receptor repertoire, including cells expressing natural cytotoxicity receptors (NCRs) and killer inhibitory receptors (KIRs), have been reported in human immunodeficiency virus (HIV) and other viral infections (7). Elevated NK cell activity has been correlated with protection against infection in several high-risk cohorts of HIV-exposed seronegative (HESN) subjects, including intravenous drug users, HIV-1-discordant couples, and perinatally exposed infants (8). Studying the role of KIR- and NCR-expressing NK cell subsets may help us understand NK cell-mediated control of early HIV infection.

Neutralization has long been viewed as the primary effector function of humoral immunity and is considered to be the primary correlate of antibody-mediated protection in HIV infection (9). However, the role of mucosal antibodies in HIV infection continues to be controversial (10). Soderlund et al. (2007) detected HIV-1-specific neutralizing $\lg \mathrm{A}$ antibodies in some infected persons, but these antibodies were unable to block the transfer of the virus from dendritic cells (DC) to susceptible target cells (11). However, Nag et al. found that HIV-1 gp120-specific IgGs in the cervical fluid could mediate antibody-dependent cellular cytotoxicity (ADCC) activity and that their levels correlated inversely with genital viral load (12).

Antibody responses are dependent mainly on $\mathrm{CD}^{+} \mathrm{T}$ cell help, and the significant subset that provides this help is the T follicular helper (Tfh) cell. These cells help in B cell affinity maturation, isotype switching, and the development of long-lived plasma cells (13). A high frequency of peripheral blood Th cells has been reported to correlate with high titers of broadly neutralizing antibodies (bNAb) and reduced viral load in HIV-infected individuals (14). Similarly, infiltration of $\mathrm{CD}^{+} \mathrm{T}$ cells into the B cell follicle area has been reported in HIV-infected individuals. More recently, Shen et al. demonstrated that $\mathrm{CXCR}^{+} \mathrm{CD}^{+} \mathrm{T}$ cells residing in the germinal center follicular area play an essential role in neutralizing virus-infected target cells (15). However, the role of CXCR5 ${ }^{+} \mathrm{CD} 8^{+} \mathrm{T}$ cells or Th cells in disease control in highly exposed uninfected individuals and the correlation of these cell types with HIV-specific antibody titers is yet to be assessed.

The cervicovaginal microbiome is a complex ecosystem with a preponderance of Lactobacillus spp. Vaginal lactobacilli prevent the colonization of the female genital tract by pathogenic microbes by maintaining an acidic $\mathrm{pH}$. In addition, the cervicovaginal mucus functions as a physical barrier for the ascent of exogenous pathogens in women with a healthy vaginal microbiome (16). Depletion of vaginal lactobacilli and cervicovaginal mucus is commonly observed among women with conditions such as bacterial vaginosis (BV), aerobic vaginitis, genital chlamydiasis, and human papilloma virus (HPV) infection (17). Many studies have reported cervicovaginal dysbiosis as an essential risk factor for the acquisition of HIV-1 infection $(16,18,19)$. Cervicovaginal colonization by bacterial species, such as Prevotella bivia, Sneathia spp., and Mycoplasma hominis, has been reported to be associated with increased concentrations of proinflammatory cytokines and chemokines in the FGT and enhanced susceptibility to HIV-1 acquisition (20-22).

The present study attempted to characterize in detail the role of mucosal NK cells, CXCR5 ${ }^{+}$ $\mathrm{CD}^{+}{ }^{+} \mathrm{T}$ cells, Tfh cells, soluble immune mediators, antiviral cytokines and chemokines, as well 
TABLE 1 Demographic and clinical characteristics of HESN and HIV-unexposed healthy women

\begin{tabular}{|c|c|c|}
\hline Parameters $^{a}$ & $\begin{array}{l}\text { HESN women }^{a} \\
(N=37)\end{array}$ & $\begin{array}{l}\text { Unexposed women } \\
(N=35)\end{array}$ \\
\hline \multicolumn{3}{|l|}{ Age, yrs } \\
\hline Median & 36 & 33 \\
\hline Range & $27-42$ & $22-42$ \\
\hline Vaginal douching & $37(100 \%)$ & $35(100 \%)$ \\
\hline Cervical cancer (HPV)-positive & 0 & 0 \\
\hline STD (BV, CT, NG)-positive & 0 & 0 \\
\hline \multicolumn{3}{|c|}{ Avg no. of sexual contacts per mo } \\
\hline With condom (median) & 2 & 2 \\
\hline Without condom (median) & 1 & 1 \\
\hline Unknown (median) & 1 & 0 \\
\hline \multicolumn{3}{|l|}{ HIV-infected partner on ART } \\
\hline Yes & $37(100 \%)$ & 0 \\
\hline NA & 0 & $35(100 \%)$ \\
\hline
\end{tabular}

a HESN, HIV-1-exposed seronegative; HPV, human papilloma virus; STD, sexually transmitted disease; BV, bacterial vaginosis; CT, Chlamydia trachomatis; NG, Neisseria gonorrhoeae; ART, antiretroviral therapy, NA, not applicable.

as the composition of the cervicovaginal microbiome in the early control of infection in HIVexposed seronegative women.

\section{RESULTS}

Sociodemographic features of the study population. There was no significant difference between the two groups for age, practice of vaginal douching, presence of bacterial vaginosis, Chlamydia trachomatis (CT), or Neisseria gonorrhoeae (NG) infection. All study participants were screened for cervical cancer by testing for HPV infection using the Pap smear test. The HESN group reported sex an average of 2 times a month with their infected partner with or without condom use. The mucosal specimens collected for this study were obtained at least a week after the last sexual act and precisely 2 weeks after the start of the last menstrual period in the volunteers (Table 1).

Presence of increased frequency of mucosal $\mathrm{CDB}^{+} \mathrm{T}$ cells expressing follicular homing receptor in HESN individuals. Studies have shown that the frequency of $\mathrm{CD}^{+} \mathrm{T}$ cells expressing the follicular homing receptor, CXCR5 correlates inversely with viral load in both human and animal models $(15,23)$. A recent study reported that elite controllers had increased numbers of $\mathrm{CXCR}^{+} \mathrm{CD}^{+} \mathrm{T}$ cells exhibiting increased effector function and suggested that these cells have a potential role in the natural control of HIV infection (24). Similarly, it is well known that follicular T helper cells play an important role in class switching and antibody production. However, the distribution of Tfh cells in the mucosal microenvironment has not been fully elucidated. Hence, we analyzed the frequencies of $\mathrm{CXCR}^{+} \mathrm{CD}^{+} \mathrm{T}$ cells, Tfh cells, and T regulatory cells (Tregs) in cytobrush specimens obtained from HESN women and compared these values with those detected in unexposed healthy $(\mathrm{UH})$ women.

To examine the frequency and distribution of follicular homing/CXCR5 ${ }^{+} \mathrm{CD} 8^{+} \mathrm{T}$ cells, Th cells, and Tregs, we stained cervical cells obtained by cytobrush sampling of the cervix of HESN and $\mathrm{UH}$ women with fluorochrome-tagged monoclonal antibodies and performed multicolor flow cytometry (Table S1; http://www.nirt.res.in/pdf/HIV/Supplemental\%20File.pdf). As previously described, $\mathrm{CD}^{+}$Tfh cells were defined as $\mathrm{CD}^{+} \mathrm{CD}^{+} 5 \mathrm{RO}^{+} \mathrm{CCR}^{+} \mathrm{PD}^{+}{ }^{+} \mathrm{CXCR}^{+} \mathrm{CXCR3}^{-}$cells (14), and follicular homing $\mathrm{CD}^{+}{ }^{+}$cells were defined as $\mathrm{CD}^{+} \mathrm{CD}^{+} 5 \mathrm{RO}^{+} \mathrm{CCR}^{+} \mathrm{PD}^{+}{ }^{+} \mathrm{CXCR} 5^{+}$ CXCR3 ${ }^{-}$cells (23). Tregs were defined as $\mathrm{CD}^{+} \mathrm{CD}^{+}{ }^{+} \mathrm{CD} 127^{-} \mathrm{CD} 25^{+}$cells (Fig. 1a).

We found that the HESN group had significantly increased numbers of mucosal follicular homing $\mathrm{CXCR}^{+} \mathrm{CD}^{+}$T cells $(P=0.017)$ (Fig. 1b) compared to the UH group. We further analyzed the expression of CXCR5 on $\mathrm{CD}^{+}$Th cells and found that the frequency of CXCR5expressing $\mathrm{CD}^{+}{ }^{+}$Tfh cells was significantly higher in the HESN group than in the UH group 

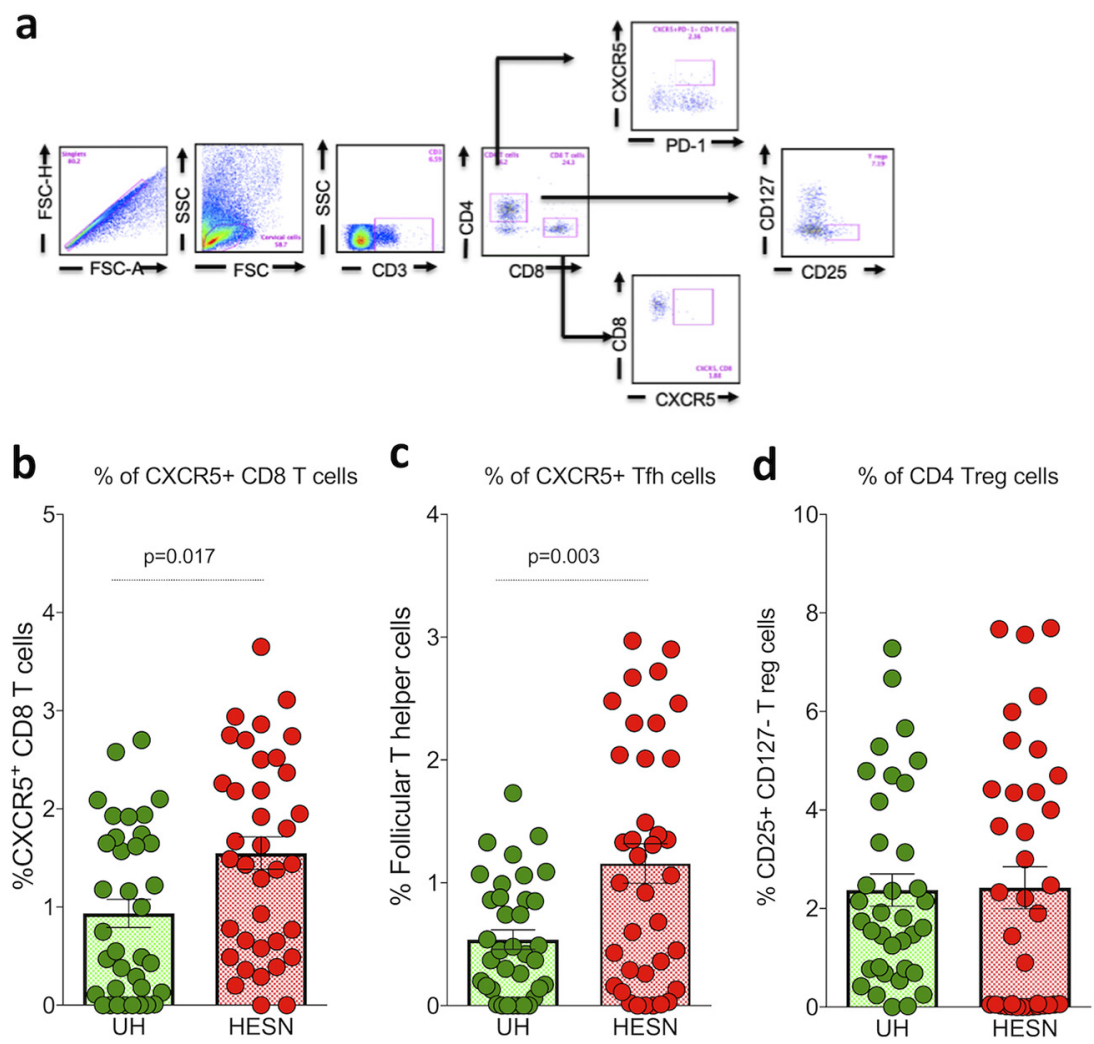

FIG 1 Mucosal $\mathrm{CXCR}^{+} \mathrm{CD}^{+} \mathrm{T}$ cells, $\mathrm{T}$ follicular helper cells and Tregs. (a) Representative flow plots showing the percent frequency of $\mathrm{CXCR5}^{+} \mathrm{T}$ cells and Tregs in the study groups (HESN, HIV-exposed seronegative [ $\mathrm{N}=37]$; $\mathrm{UH}$, HIV-unexposed seronegative $[\mathrm{N}=35]$ ). (b) Figure showing the cumulative frequency of $\mathrm{CXCR}^{+} \mathrm{CD}^{+} \mathrm{T}$ cells in the HESN and UH groups. (c) Figure showing the cumulative frequency of $T$ follicular helper cells in the HESN and UH groups. (d) Figure showing the cumulative frequency of $\mathrm{CD} 127^{-} \mathrm{CD} 25^{+} \mathrm{T}$ regs in the HESN and UH groups. The scatter dot plots summarize the percent frequency of total $\mathrm{CD} 8^{+} \mathrm{CXCR5}^{+} \mathrm{T}$ cells, Tfh cells, and Tregs (median, 1st, and 3rd quartiles). $P$ values were determined using the Mann-Whitney test.

$(P=0.003)$ (Fig. 1c). The median frequency of mucosal CXCR5 $5^{+} \mathrm{CD} 8^{+} \mathrm{T}$ cells was $1.49 \%$ (range, 0.65 to $2.37 \%$ ) compared to $0.65 \%$ (range, 0.11 to $1.69 \%$ ) in the UH group, and the median frequency of mucosal Tfh cells among the $\mathrm{CD}^{+} \mathrm{T}$ cell subset was $1.06 \%$ (range, 0.26 to $2.01 \%$ ) in the HESN group compared to $0.44 \%$ (range, 0.14 to $0.87 \%$ ) in the UH group. However, there was no difference in the distribution of mucosal T regulatory cells between the HESN and UH groups (Fig. 1d).

Abundance of natural cytotoxicity receptor-expressing NK cells in the cervical mucosa of HESN individuals. NK cell-mediated antiviral effector function and ADCC mediated by NK cells and antiviral antibodies have been implicated in the control of HIV infection $(25,26)$. This evidence suggests a role for NK cells in the control of HIV and opens up a new avenue for research in the development of HIV vaccines (27). However, NK cell function and distribution in the mucosal tissue are not fully understood. We analyzed the distribution of NK cells expressing NCRs and KIRs in the genital mucosa of HESN women and UH women using multicolor flow cytometry on cells present in the cervical cytobrush specimens. NK cells expressing activating natural cytotoxicity receptors (Table S2; http://www.nirt.res.in/pdf/HIV/ Supplemental\%20File.pdf) were defined as $\mathrm{CD}^{-} \mathrm{CD}^{-} 6^{+} \mathrm{CD}_{6} 6^{+} \mathrm{CD}_{2} 7^{+} \mathrm{NKG} 2 \mathrm{D}^{+} \mathrm{Nkp} 30^{+}$/ $\mathrm{Nkp} 44^{+} / \mathrm{Nkp} 6^{+}$cells, and NK cells expressing inhibitory killer cell immunoglobulin-like receptors were defined as $\mathrm{CD} 3^{-} \mathrm{CD} 16^{+} \mathrm{CD} 56^{+} \mathrm{CD}^{2} 7^{+} \mathrm{KLRG}^{+} \mathrm{CD} 158 \mathrm{a}^{+} / \mathrm{CD} 158 \mathrm{~b}^{+} / \mathrm{CD} 158 \mathrm{e} 1^{+}$cells as described by Kulkarni et al. (5) (Fig. S1 and S2; http://www.nirt.res.in/pdf/HIV/Supplemental\% 20File.pdf).

We found significantly higher frequencies of NK cells expressing NCRs, such as Nkp30, Nkp44, and Nkp46, in the genital mucosa of HESN women than in UH women. We performed 
a

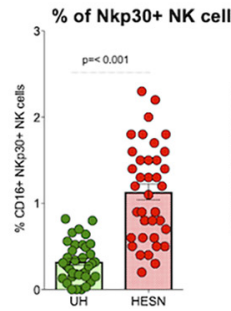

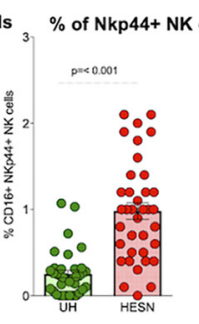
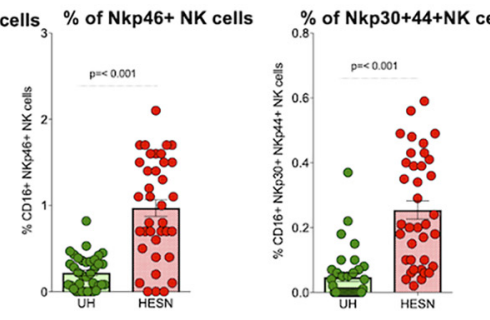

b

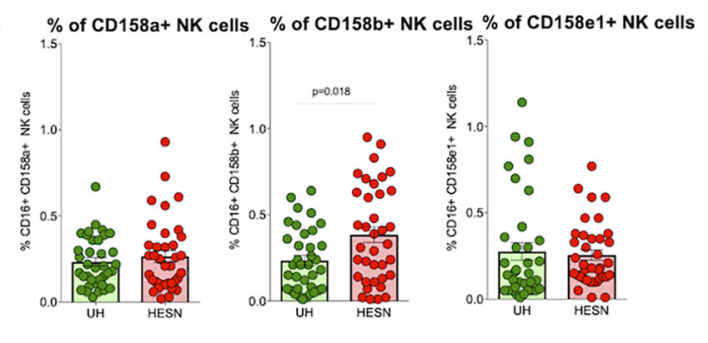

C

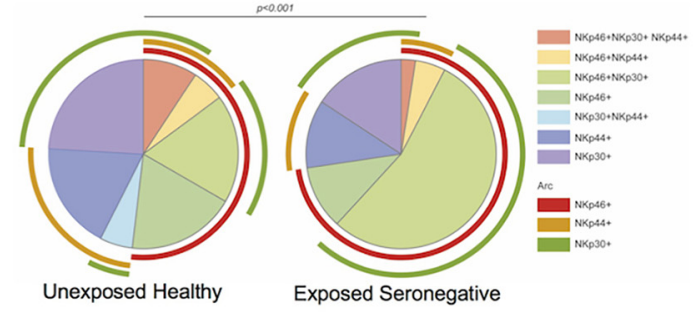

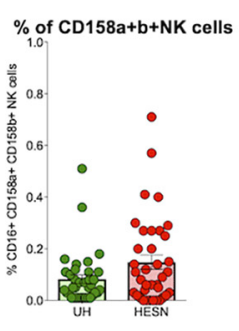
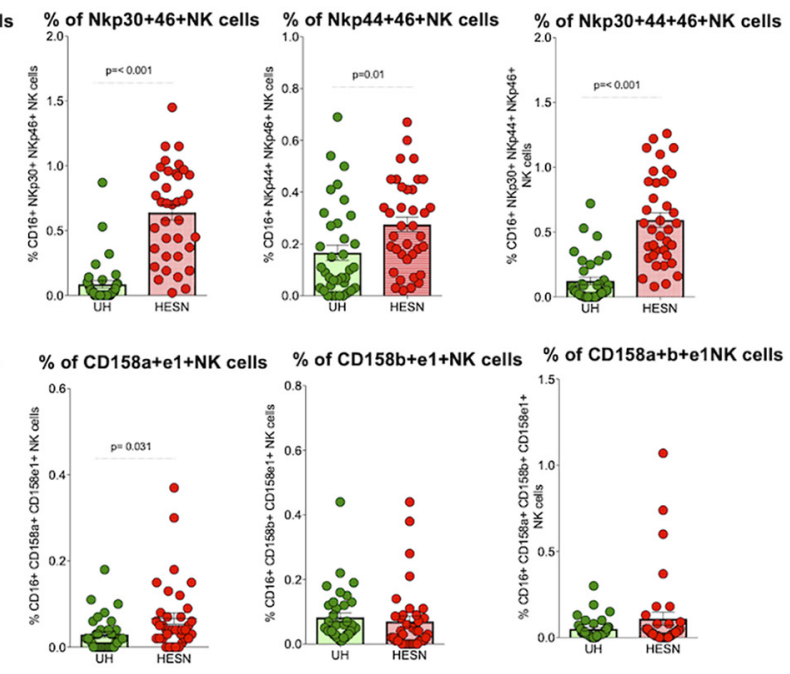

d

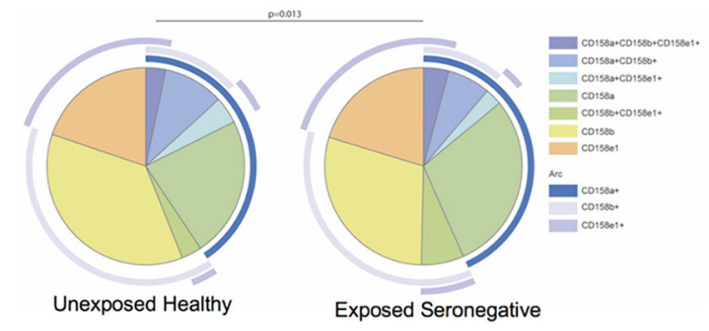

FIG 2 Distribution of natural cytotoxicity receptor (NCR)- and killer cell immunoglobulin-like inhibitory receptor (KIR)-coexpressing mucosal NK cells. (a) Proportion of NK cells expressing each activating receptor (Nkp30, Nkp44, Nkp46). (b) Proportion of NK cells expressing each inhibitory receptor (CD158a, CD158b, CD158e1). The scatter dot plots summarize the percent frequency of total NCR- and KIR-expressing NK cells from cytobrush specimens (HESN, HIVexposed seronegative $[N=37]$; UH, HIV-unexposed seronegative $[N=35])$. The graphical plots show the median, 25th, and 75th percentiles and interquartile range (IQR). $P$ values were determined using the Mann-Whitney test. (c) SPICE analysis of different combinations of NCR-expressing NK cells indicated statistically significant differences in the permutation of different combinations. (d) SPICE analysis of the different combination of KIR-expressing NK cells indicated statistically significant differences in the permutation of different combinations.

Boolean analysis of NCR-expressing cells to identify multiple receptor-expressing cells and

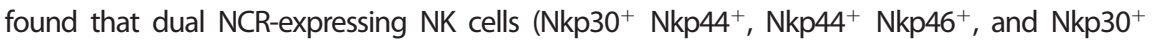
$\mathrm{Nkp}^{4} 6^{+}$) were also significantly elevated in the HESN group (Fig. 2a). In contrast, the frequency of NK cells expressing inhibitory receptors was similar in the HESN and UH groups. However, $\mathrm{CD}_{158 \mathrm{~b}^{+}}$and $\mathrm{CD} 158 \mathrm{a}^{+} \mathrm{CD} 158 \mathrm{e} 1^{+}$dual receptor-expressing NK cells alone were found to be significantly higher in the genital mucosa of HESN women than in UH women $(P=0.018$ and $P=0.031$, respectively) (Fig. $2 \mathrm{~b}$ ).

We also found that NK cells expressing all $3 \mathrm{NCRs}\left({\mathrm{Nkp} 30^{+}}^{+} \mathrm{Nkp} 44^{+} \mathrm{Nkp} 46^{+}\right)$were significantly more abundant in the HESN group. However, there was no difference in the frequency of NK cells expressing multiple KIRs (CD158a $a^{+} \mathrm{CD} 158 \mathrm{~b}^{+} \mathrm{CD} 158 \mathrm{e} 1^{+}$cells) between the HESN and $\mathrm{UH}$ groups $(P>0.950)$. These data taken together demonstrate that NK cells expressing NCRs are more abundant in the mucosa of HESN women than in UH women (Fig. $2 \mathrm{c}$ and d).

Increased levels of total secretory IgG and IgA in the mucosal microenvironment of HESN individuals. Mucosal immunoglobulin (IgG, $\lg A$, and $\lg M$ ) levels were determined in the study participants' cervicovaginal lavage using a BD cytometric bead array. We found increased levels of total IgG and IgA in HESN women compared to in UH women. The median level of mucosal lgG was $10,000 \mathrm{ng} / \mathrm{ml}(2,874$ to $55,454 \mathrm{ng} / \mathrm{ml})$ in the HESN group and $454 \mathrm{ng} / \mathrm{ml}(101$ to $3,516 \mathrm{ng} / \mathrm{ml})$ in the UH group. The median level of mucosal lgA was $6,447 \mathrm{ng} / \mathrm{ml}(1,984$ to $11,442 \mathrm{ng} / \mathrm{ml})$ in the HESN group and $1,955 \mathrm{ng} / \mathrm{ml}(487$ to $7,351 \mathrm{ng} /$ $\mathrm{ml})$ in the UH group. Thus, it is evident that the HESN participants had significantly higher levels of total IgG and IgA in their cervicovaginal secretions than UH women (IgG, $P<0.001$; $\lg A, P=0.024)$; however, there was no significant difference in IgM levels between the two groups (Fig. 3). 


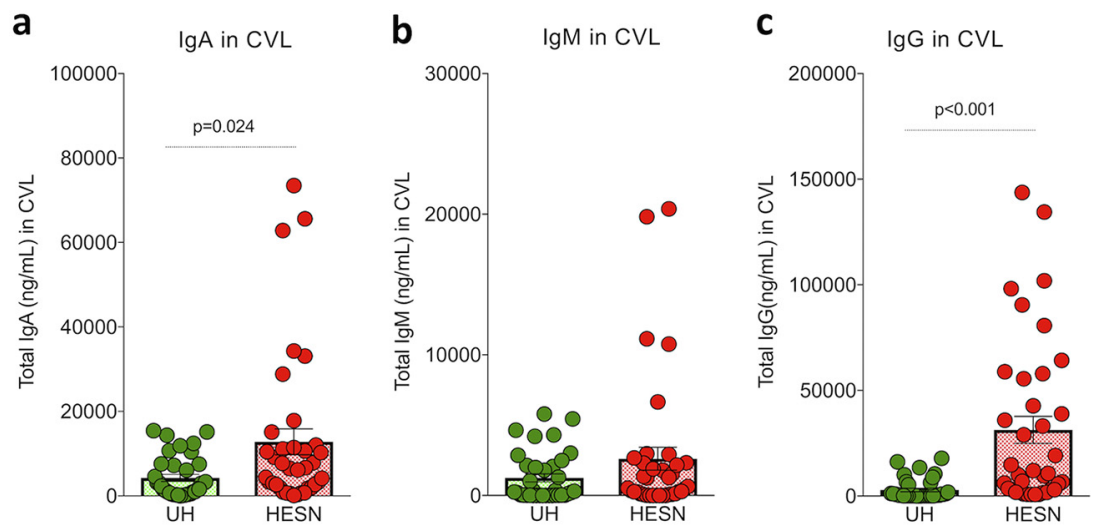

FIG 3 Levels of mucosal immunoglobulins (IgG, IgA, and IgM) in cervical vaginal lavage. Mucosal immunoglobulin (IgG, IgA, and IgM) levels in CVL specimens measured by cytometric bead array and reported in $\mathrm{ng} / \mathrm{ml}$. (a) Total IgA level in cervicovaginal lavage. (b) Total IgM level in cervicovaginal lavage. (c) Total lgG level in cervicovaginal lavage. The box-and-whisker plots represent median, 25th, and 75 th percentiles and range (IQR). $P$ values were determined using the Mann-Whitney test. (HESN, HIV-exposed seronegative [ $\mathrm{N}=37]$; UH, HIV-unexposed seronegative $[N=35]$ ).

Differences in dynamics of proinflammatory molecules, antiviral cytokines, and chemokines in the cervicovaginal secretions of HESN individuals. Earlier studies that reported elevated antiviral responses against HIV in HIV controllers, slow progressors, and HIV-exposed seronegative individuals $(27,28)$ have demonstrated a significant role for cytokines and chemokines in HIV disease progression (29). As part of our analysis, we measured antiviral cytokines and chemokines in the cervicovaginal lavage of HESN and UH individuals using a cytometric bead assay (LEGENDplex).

a Antiviral Cytokines \& Chemokines ( $\mathrm{pg} / \mathrm{mL})$

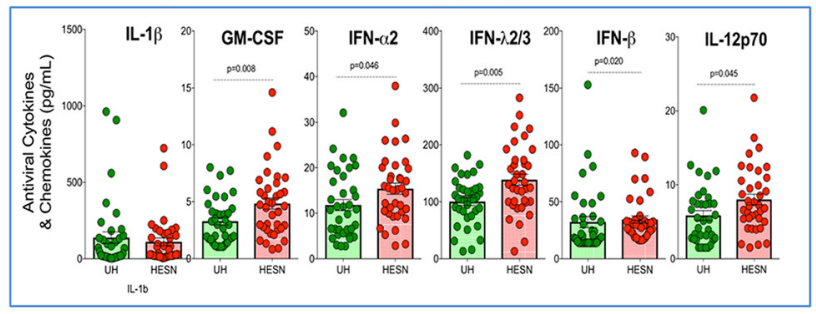

C CD8/NK cell specific Cytokines \& Chemokines $(\mathrm{pg} / \mathrm{mL})$

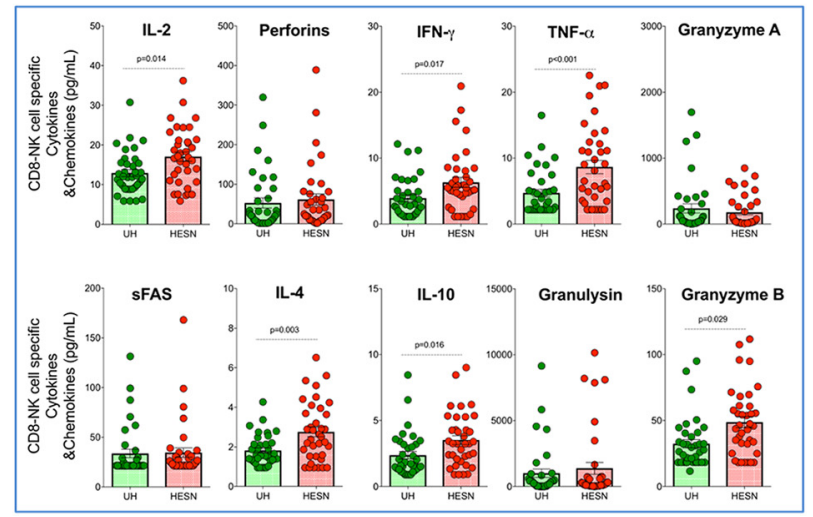

b T helper Cytokines \& Chemokines $(\mathrm{pg} / \mathrm{mL})$

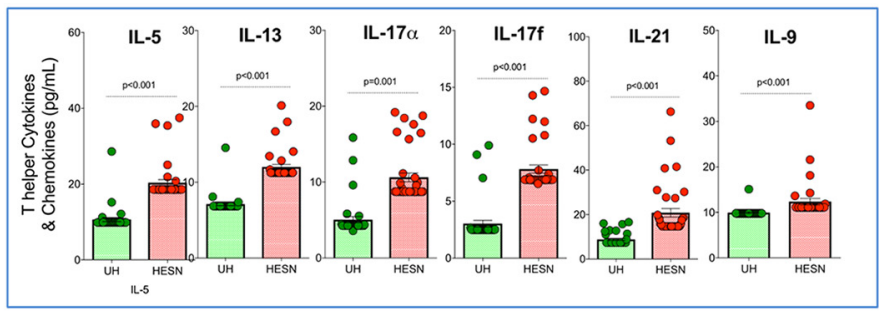

d Pro-inflammatory Cytokines \& Chemokines $(\mathrm{pg} / \mathrm{mL})$

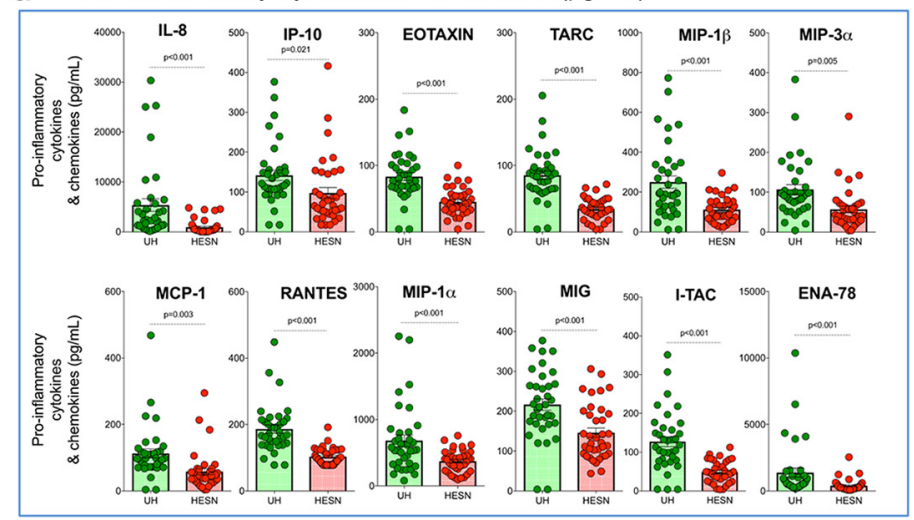

FIG 4 Levels of antiviral mediators, T helper cell-specific and $\mathrm{CD}^{+} \mathrm{T}$ cell/NK cell-specific effector molecules, cytokines and chemokines in the cervicovaginal lavage. Levels of (a) antiviral molecules (IL-1, GM-CSF, IFN-2, IFN- $\lambda 2 / 3$, IFN-, IL-12p70), (b) T helper cell cytokines (IL-5, IL-13, IL-17 $\alpha$, IL-17f, IL-21, IL-9), (c) CD8/NK cell specific cytokines (IL-2, perforin, IFN- $\gamma$, TNF- $\alpha$, granzyme A, sFAS, IL-4, IL-10, granulysin, granzyme B) (d) Pro-inflammatory chemokines (IL-8, IP-10, EOTAXIN, TARC, MIP-1 $\beta$, MIP-3 $\alpha$ MCP-1, RANTES, MIP-1, MIG, I-TAC, ENA-78), in the CVL of HESN $(N=37)$ and UH ( $N=35)$ groups. The data shown is the median level of cytokines and chemokines $(\mathrm{pg} / \mathrm{ml})$. The scatter dot plots show the median, 25th, and 75 th percentiles and range (IQR). $P$ values were determined using the Mann-Whitney test. HESN, HIV exposed seronegative; UH, HIV unexposed seronegative. 

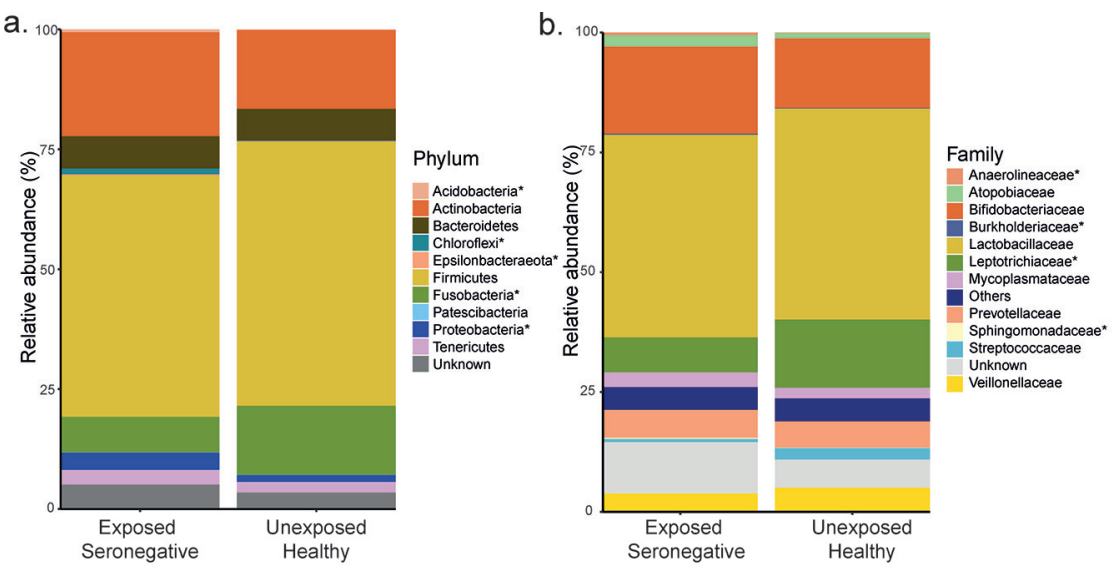

d.

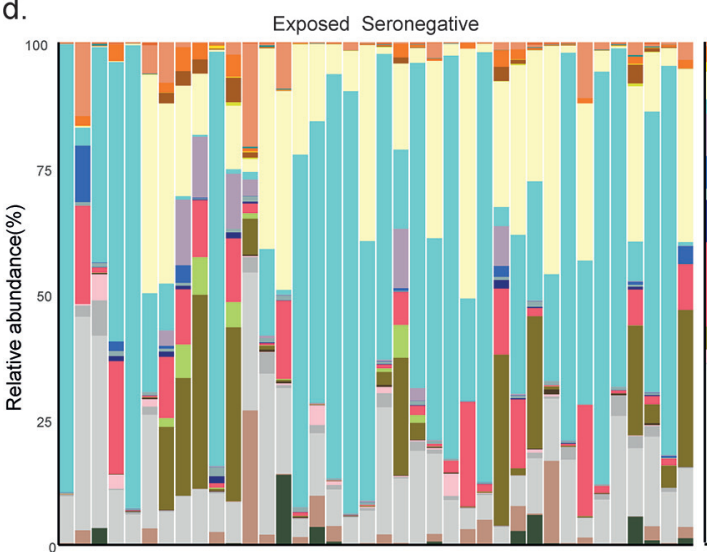

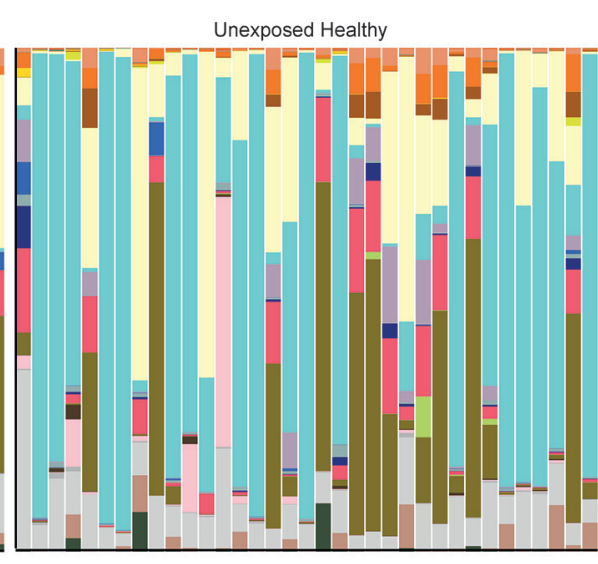

C.

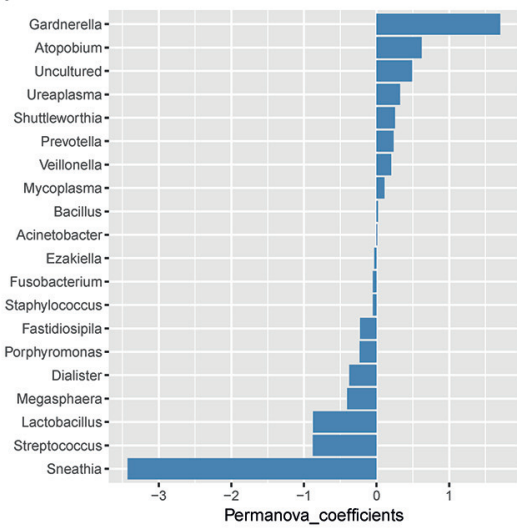

e.

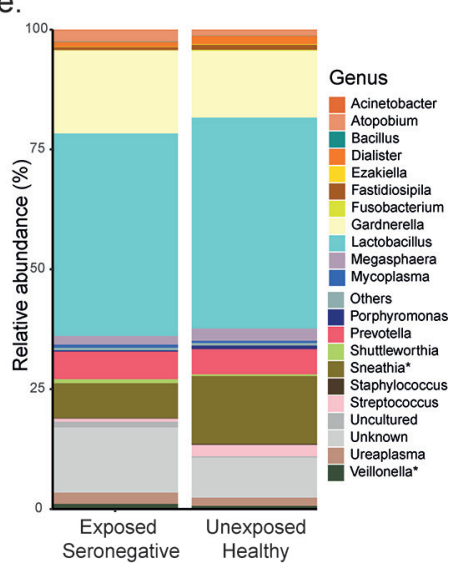

FIG 5 Composition of the cervicovaginal microbiome in the study population. (a) Mean relative abundance in the phylum. (b) Mean relative abundance in family. (c) Top 20 taxa at the genus level that have a significant effect on separating the groups as per PERMANOVA analysis. (d) Visualization of samplewise relative abundance (\%) in the two experimental groups. (e) Mean relative abundance in genus. The asterisk (*) denotes significance in the MannWhitney test.

Significantly elevated levels of several T cell/NK cell cytokines and soluble factors, such as interleukin-2 (IL-2), interferon- $\gamma$ (IFN- $\gamma$ ), tumor necrosis factor- $\alpha$ (TNF- $\alpha$ ), IL-17 $\alpha$, IL-17f, IL-21, IL-4, IL-5, IL-9, IL-10, IL-13, and granzyme B, were detected in the HESN group (Fig. $4 \mathrm{~b}$ and $4 \mathrm{c}$ ). The HESN cohort also had significantly higher levels of antiviral cytokines, such as IFN- $\alpha 2$, IFN- $\beta$, IFN- $\lambda 2 / 3$, IL-12p70, and granulocyte-macrophage colony-stimulating factor (GM-CSF) (Fig. 4a) (Table S4; http://www.nirt.res.in/pdf/HIV/ Supplemental\%20File.pdf). In contrast, levels of all the proinflammatory chemokines measured were found to be significantly lower in the HESN group. These included interleukin-8 (IL-8), interferon- $\gamma$-induced protein $10 \mathrm{kDa}$ IFN-gamma-inducible protein 10 (IP-10), eotaxin, thymus- and activation-regulated chemokine (TARC), monocyte chemoattractant protein 1 (MCP-1), RANTES, macrophage inflammatory protein-1 $\alpha$ (MIP-1 $\alpha$ ), MIP-1 $\beta$, monokine induced by gamma (MIG), epithelial-neutrophil activating peptide (ENA-78), MIP-3 $\alpha$, human growth regulated oncogene alpha (GRO $\alpha$ ), and interferon-inducible T cell alpha chemoattractant (I-TAC) (Fig. 4d; Table S5; http://www.nirt .res.in/pdf/HIV/Supplemental\%20File.pdf). These findings suggest that the mucosal microenvironment in HESN individuals is more quiescent and has a good supply of antiviral effector cytokines and chemokines, which makes it unsuitable for the establishment of HIV infection.

Composition of the cervicovaginal microbiome differs between the HESN and UH groups. Microbiome analysis revealed that bacteria belonging to the phyla Proteobacteria, Epsilonbacteraeota, Acidobacteria, and Chloroflexi were relatively more abundant $(P<0.001)$ in the HESN group than in the UH group (Fig. 5a). The family-level relative abundance of the microflora in the two groups is presented in Fig. 5b. Group-wise comparison of the 
a.

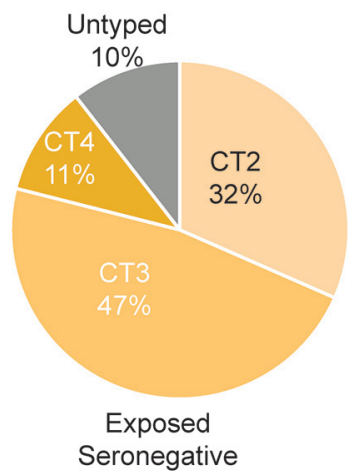

c.

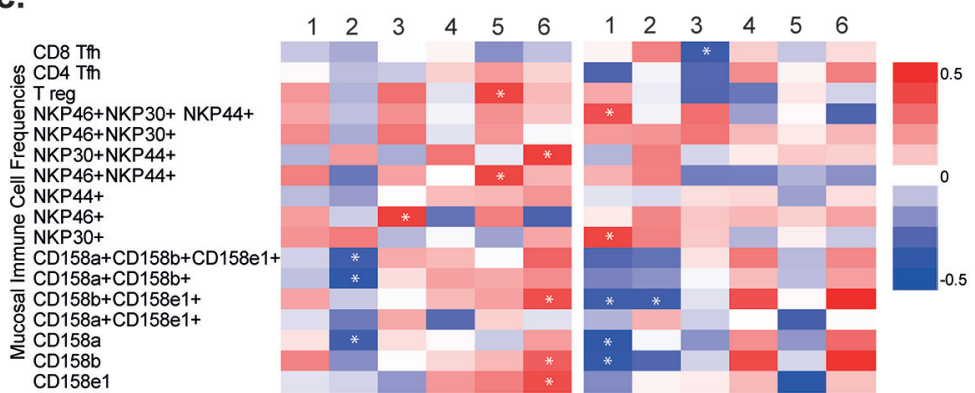

b.
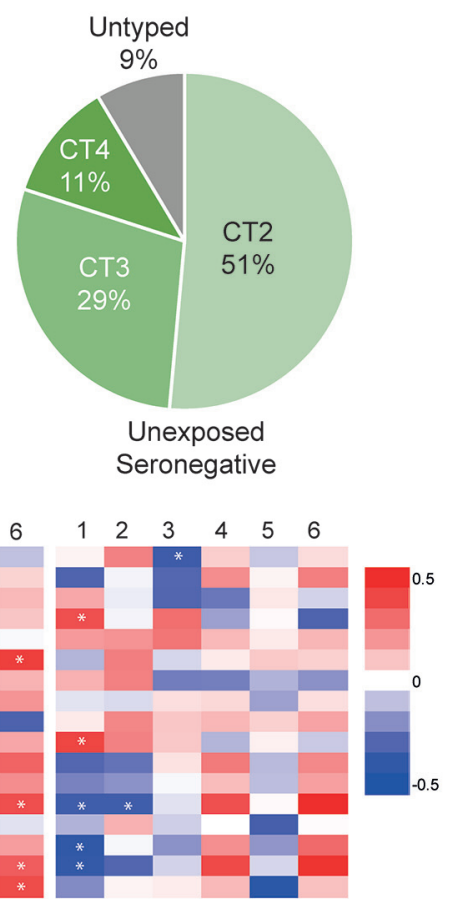

FIG 6 Distribution of bacterial species and their association with inflammation. (a) Distribution of CT2, CT3, and CT4 bacteria in HESN and UH women. (b) Bar graph showing average relative abundance (\%) of various species. The asterisk (*) denotes significance in the Mann-Whitney test. (c) Heat map showing Spearman's correlation values between significant species (from Mann-Whitney test) and mucosal immune cell frequencies. The asterisk (*) denotes a significant correlation.

microbiome composition at the genus level was performed using a permutational multivariate analysis of variance (PERMANOVA), which indicated that Gardnerella had the highest PERMANOVA coefficient (Fig. 5c). Our findings are in agreement with previous observations of higher abundance of Gardnerella and intermediate abundance of Lactobacillus spp. in highly exposed commercial sex workers from the Nairobi cohort (30). Microbiome distribution at the genus level is shown in Fig. $5 d$ and 5 e. At the species level, we found that a majority (51\%) of the UH women had a preponderance of $L$. iners (cervicotype-2 [CT-2] flora), followed by Gardnerella vaginalis (CT-3 flora) in 29\% and mixed anaerobic bacteria (CT-4 flora) in 11\% (Fig. 6a). Among the HESN group, CT-2, CT-3, and CT-4 flora were observed in 32, 47, and 11\% of the women, respectively. The comprehensive cervicotype classification system was adapted from Anahtar et al. (21). Taken together, our findings reveal significantly higher microbial diversity (abnormal flora belonging to CT-3 and CT-4) in the HESN cohort (58\%) than in the control group (40\%) (Fig. 6a). Statistically significant differences were detected between the study groups in the relative abundance of Veillonella montpellierensis, L. gasseri, L. crispatus, Prevotella amnii, Sneathia amnii, and Streptococcus agalactiae (Fig. 6b). While Veillonella montpellierensis, L. gasseri, and L. crispatus were more abundant in the HESN group, Prevotella amnii, Sneathia amnii, and Streptococcus agalactiae were more common in the UH group (Fig. 6b). Higher abundance of ungrouped bacteria was also observed in the HESN group than in the UH group in our cohort.

Interestingly, we observed a positive correlation between the frequency of mucosal NCR- and KIR-expressing NK cell subsets and L. gasseri, L. crispatus, Veillonella montpellierensis, Prevotella amnii, and Sneathia amnii in the HESN population. A significant correla-

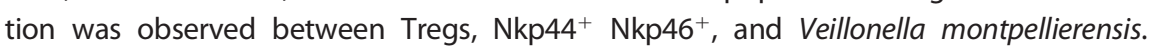
Similarly, $\mathrm{Nkp} 30^{+} \mathrm{Nkp}_{4}{ }^{+}, \mathrm{CD}_{158 b^{+}} \mathrm{CD} 158 \mathrm{e} 1^{+}, \mathrm{CD} 158 \mathrm{e} 1^{+}$, and $\mathrm{CD} 158 \mathrm{~b}^{+}$significantly correlated with Sneathia amnii. On the other hand, in UH individuals, NK cells expressing $\mathrm{Nkp} 30^{+}, \mathrm{Nkp} 46^{+}, \mathrm{Nkp} 44^{+}$, and $\mathrm{Nkp30} 0^{+}$were significantly associated with L. gasseri. The correlation observed between bacterial species and immunological markers in the study groups is shown in Fig. $6 c$. The positive association with immune cell frequencies and 
higher microbial diversity in the HESN group suggests that the increased colonization of the genital mucosa with diverse microbial species might lead to increased recruitment of critical components of the innate immune system that coordinate the early control of HIV infection. The intricate role of mucosal immune cell activation in determining the pattern and diversity of the local microbiome remains incompletely understood. Understanding the interplay between the microbiome and the innate and adaptive immune system may shed light on some of the critical events that orchestrate protection against HIV infection.

\section{DISCUSSION}

Mucosal immune responses present at the surfaces that serve as points of contact with the pathogen are believed to play a critical role in controlling/preventing HIV infection (31). Innate immune responses are the first line of defense against microbes (32). Earlier studies have documented that host factors present in the FGT, including the natural microbiota, play a role in both protection and susceptibility to infection (1, 33). Protective mucosal responses against HIV are best characterized in individuals who remain relatively resistant to HIV infection despite repeated exposure (34). This phenomenon has been documented in many groups, including commercial sex workers (35), serodiscordant couples (36), infants born to HIV-infected mothers, and others. Longterm nonprogressors (LTNPs) constitute another group of individuals who are HIV infected but relatively resistant to disease progression. These individuals sometimes share common immunological features with HIV controllers and have been used to understand the correlates of resistance/susceptibility to HIV infection and disease progression $(1,36,37)$.

Several correlates of protection against HIV infection have been previously described in both systemic and genital compartments. HIV-specific CD8 ${ }^{+}$T cell responses (38-40) and the presence of anti-HIV IgA (41) have been implicated as markers of protection or indicators of exposure (42). Increased levels of the molecules RANTES, serpin B, alpha-2 macroglobulinlike molecule, and cystatin have been correlated with resistance to infection (43). Although multiple correlates of resistance to infection and/disease progression have been described, the mechanisms through which the different factors operate have not been deciphered. Many future investigations are required to understand the mechanisms involved in the protection against HIV-1 infection.

Characterizing the subset of innate immune cells like the NK cells present in the FGT may help us to understand the nature of the innate immune mechanisms operating in the mucosal microenvironment and provide a clue to the development of an adaptive immune process. An earlier study reported elevated levels of NK cell activity and higher secretion of NK cell-specific cytokines in highly exposed uninfected intravenous drug users compared to controls (44). In addition to the evidence supporting the role of NK cells and elevated levels of IFN- $\gamma$ in mediating control of HIV infection, changes in expression of different cell surface receptors on NK cells have also been implicated in HIV infection and control (45).

Stimulation of NK cell cytotoxicity involves interaction between target cell antigens and stimulatory surface receptors on NK cells $(5,46-48)$. Wang et al. reported that elevated expression of NCR correlated with low viremia and that NKp30 plays a significant role in NK cell activation, degranulation, and cytotoxicity (4). Another study reported that increased expression of activating receptors and potency of cytotoxic NK cells correlated with reduced viral load in recently infected individuals and long-term nonprogressors (5). Our study also found significantly higher levels of NK cells expressing NKp46, NKp44, and NKp30 in the HESN cohort than in the UH population. We further analyzed frequencies of dual receptorand triple receptor-expressing NK cells using Boolean gating and found that the proportion of activated NK cells expressing multiple NCRs was also significantly higher in the HESN cohort. This observation supports the hypothesis that the activating receptor-expressing NK cell subset might have a role to play in the early control of HIV infection. We also examined the expression of inhibitory receptors (CD158a, CD158b, CD158e1, and NKG2A) on NK cells and found that the proportion of cells expressing these receptors was correspondingly lower in the HESN group than in the UH group. Alter et al. also suggested that activating KIRs, or 
weakly inhibitory KIRs, may have a significant role to play in viral infections (7). Zwolinska et al. found that the frequency of NK cells expressing KIRs was elevated during HIV disease progression and suggested a role for these cells in regulating the exaggerated innate and adaptive antiviral response (49). Studies done in African female sex workers (FSWs) have shown decreased genetic pairing of inhibitory KIRs with HLA ligand, leading to a decrease in inhibitory signaling. These observations support a role for NK cells in protecting against virus transmission and demonstrate that improved NK activation or reduced NK inhibition is linked with resistance to HIV infection $(50,51)$.

High levels of inflammatory cytokines and tissue damage in the FGT have been suggested to increase susceptibility to HIV infection (52). Earlier studies have documented increased inflammation in the FGT of healthy donors compared to the periphery. These observations suggest that decreased levels of proinflammatory mediators in the FGT would lower inflammation of the mucosa and reduce the risk of HIV acquisition. The findings of our study provide evidence for decreased levels of proinflammatory mediators in the mucosa of HESN women compared to UH women as well as higher levels of antiviral molecules, such as type I and III interferons and cytotoxic effector molecules, suggesting that mechanisms are in place to control inflammation of the FGT in HESN women while responding to low-level viral replication. Lajoie et al. showed that the mucosal immune system of FSWs is less activated than that of low-risk HIV-negative women; they also found that this group of individuals had much lower mucosal levels of proinflammatory cytokines/chemokines than sexually active non-FSWs (53). These findings indicate that low levels of mucosal immune activation trigger the local innate response without increasing the number of potential target cells (53). Our study also found lower levels of proinflammatory cytokines in the mucosal compartment of HESN women than in UH individuals. Lower levels of proinflammatory molecules in the mucosa possibly contribute to the integrity of the genital mucosa by controlling inflammation and maintaining tight junctions, thus favoring the control of HIV infection. It is, therefore, crucial to consider the genital tract as a separate entity when studying HIV-1 transmission and evaluating HIV resistance.

Few studies in HESN individuals have shown that these individuals have neutralizing $\lg \mathrm{A}$ antibodies in the genital mucosa, which could protect against infection (54). Some reports have suggested that the presence of anti-HIV IgA antibodies in genital secretions correlates more strongly with exposure than resistance to HIV infection (42). In the present study, we measured total $\operatorname{lgG}$, IgA, and IgM in the cervicovaginal lavage (CVL) specimens of HESN and UH cohorts and observed elevated levels of IgA and IgG in the HESN group compared to the UH group. However, there was no difference in the level of IgM between the two groups. Although the study did not measure HIV-specific antibodies, we hypothesize that the abundance of antibodies at the mucosal surface of HESN women may contribute to protection against HIV infection, perhaps by the indirect killing of HIV-infected cells through antibody-dependent cell-mediated cytotoxicity coordinated by NK cells (55).

Antibody responses typically require $\mathrm{CD}^{+} \mathrm{T}$ cell help, and the major helper subset that provides this help is the T follicular helper (Tfh) cell (56) that primes B cells to produce antibodies. In HIV-infected individuals, a high frequency of circulating Tfh cells has been found to correlate with high titers of broadly neutralizing antibodies (bNAb) and reduced viral load $(14,57)$. Sivasankaran et al. reported that a subtype C-specific HIV vaccine induced circulating memory-like Tfh cells that correlated positively with variable region-specific antibody production (58). More recent studies have shown that $\mathrm{CXCR}^{+} \mathrm{CD}^{+} \mathrm{T}$ cells traffic into the $\mathrm{B}$ cell follicle area of simian immunodeficiency virus (SIV)-infected rhesus macaques and suppress residual viral replication (59). In the present study, we evaluated the frequencies of mucosal $\mathrm{CD}^{+}{ }^{+} \mathrm{Tfh}$ and $\mathrm{CXCR}^{+} \mathrm{CD}^{+}$T cells in cytobrush specimens and found elevated levels of these T cell subsets in HESN women compared to UH women.

However, in a parallel study, we also analyzed the systemic immune response in HESN individuals and compared it with that seen in HIV-infected women on antiretroviral therapy (ART) as well as those who were naive to ART from another cohort along with UH women. We found significantly elevated frequencies of CXCR5 ${ }^{+}$CD8 T cells and polyfunctional T cells, with stem cell likeness in HESN individuals. In addition, we also demonstrated 
a potent in vitro viral inhibition activity in the HESN population compared to HIV-infected and HIV-unexposed counterparts (60). To our knowledge, this is the first study reporting higher frequencies of Tfh and $\mathrm{CXCR}^{+} \mathrm{CD}^{+} \mathrm{T}$ cells in HESN cohorts from India. These results suggest that the induction of mucosal $\mathrm{CD}^{+}{ }^{+}$Tfh cells and $\mathrm{CXCR} 5^{+} \mathrm{CD} 8^{+} \mathrm{T}$ cells might contribute to the early control of infection, possibly through induction of a significant antibody response or some other unknown mechanism to eradicate infected cells at the mucosal level.

HIV infection results in the production of proinflammatory cytokines, and their levels increase with the progression of HIV disease (61). Many soluble mediators can suppress HIV replication in vitro (62). The number of cytokines produced and cytokine receptor density on the host cell surface are believed to be key determinants for the control of HIV infection (61). Many innate soluble markers possess an inhibitory effect on HIV, including $\alpha, \beta$, and $\theta$ defensins, IL-6, IL-10, IL-16, TNF- $\alpha$, interleukin- $1 \beta$, and type I interferons $\alpha$ and $\beta$ (63). In the present study, we analyzed several antiviral cytokines and chemokines in the CVL of HESN and UH women using a cytometric bead array and observed significantly elevated levels of IL-12p70, IFN- $\alpha 2$, IFN- $\lambda 2 / 3$, GM-CSF, IFN- $\beta$, and IL-10 in the HESN group. We also analyzed cytokines produced by CD8 and NK cells among others and found that IL-2, IL-4, IL-10, TNF$\alpha$, IFN- $\gamma$, and granzyme B were present at significantly increased levels in HESN women. Additionally, soluble Fas (sFas), soluble Fas ligand (sFasL), and perforin levels were also higher in the mucosal compartment of HESN women, although the difference between groups was not significant. Furthermore, we analyzed the levels of Th cytokines and found that IL-5, IL-13, IL-9, IL-17 $\alpha$, IL-17f, IL-21, and IL-22 were very high in HESN women. The presence of high levels of immune cell-specific cytokines and antiviral cytokines and chemokines at the mucosal surface is thought to be instrumental in instructing the development of different types of immune mechanisms that contribute to the early control of HIV infection.

The cervicovaginal microbiome is a dynamic ecosystem, and the diversity of its composition can vary due to multiple factors, including ethnicity, socioeconomic status, level of education, sexual behavior, and lifestyle factors (18). An interesting finding from the present study concerning the cervicovaginal microbiome was a higher relative abundance of $L$. iners in both groups than of $L$. crispatus, unlike in other studies $(21,22,64)$. Reasons for the low abundance of $L$. crispatus in our cohort could not be assessed due to the lack of epidemiological data (socioeconomic status, level of education, and lifestyle factors) regarding vaginal health status (by Gram-stained smear examination) of the study participants. Low et al. reported that intravaginal practices, as well as the presence of bacterial vaginosis (BV), can increase the risk of HIV acquisition. However, intravaginal cleaning with soap, causes disruption of vaginal flora, and usage of vaginal microbicides can reduce the likelihood of HIV acquisition (19). In a recent study on South African women, it was reported that women with a predominance of $L$. crispatus were more resistant to the acquisition of HIV than those with a predominance of $L$. iners and other anaerobic bacterial flora. The investigators also reported an increase in proinflammatory cytokines among women colonized with bacteria such as Vellionella montpellierensis, Prevotella bivia, and Sneathia sanguinegens (22). However, in the present study, we observed a predominance of $L$. iners and a high level of diversity in the cervicovaginal microbiome of HESN individuals. Studies report that a Lactobacillus-dominant vaginal microbiota generally reflects vaginal health and is associated with a decreased risk of HIV acquisition (16, 22). We observed higher abundance of $L$. crispatus in the HESN group and a low level of proinflammatory mediators that may help maintain mucosal surface integrity and reduce the risk of HIV acquisition in these individuals. Further, we observed a correlation between mucosal NCRexpressing, activated NK cells and mucosal microbiota in HESN women, suggesting that immune cell trafficking and activation of immune cells in the cervicovaginal surfaces may reduce the risk of HIV infection in association with vaginal dysbiosis.

To summarize, the majority of HIV infections occur via the vaginal or rectal route, and, therefore, many researchers believe that a strong preexisting immune response in the mucosa-associated lymphoid tissue (MALT) may be able to protect against HIV infection. In addition to antigen-specific adaptive immune responses, which were not evaluated in this study, there is mounting evidence that factors associated with 
inflammation, or alternatively immune quiescence, may contribute to HIV susceptibility at the mucosal surface $(28,38)$. The present study explored some of the immune mechanisms operating in the mucosal microenvironment of HESN women and identified mucosal natural cytotoxicity receptor-expressing NK cells, $\mathrm{CXCR5}^{+} \mathrm{CD}^{+} \mathrm{T}$ cells, follicular T helper cells, and soluble markers as well as a highly diverse cervicovaginal microbiome as potential correlates of protection against HIV-1 infection. As an additional control group, we originally planned to recruit HIV-positive women not on antiretroviral therapy. However, due to implementation of the Treat All policy as required by the new National Technical Guidelines for Antiretroviral Therapy (2017), we were unable to recruit any ART-naive women. However, further investigation is necessary to determine the functional capabilities of these factors in abrogating HIV infection. The multifactorial nature of HIV resistance emphasizes the importance of the interplay between immune cells and the composition of the vaginal microbiome at the mucosal level. Further understanding in this line would help us to devise strategies to enhance useful innate and adaptive immune responses to prevent HIV infection. This knowledge would also prove to be useful for the identification of novel candidate vaccines.

\section{MATERIALS AND METHODS}

Ethics statement. The study protocol was approved by the Scientific Advisory Committee of the Indian Council of Medical Research (ICMR)-National Institute for Research in Tuberculosis (NIRT), Chennai, India. The study was conducted under good clinical laboratory practice (GCLP) guidelines. The study protocol was reviewed and approved by the Institutional Ethics Committee of ICMR-NIRT (IEC ID-2015015) and the Institutional Review Board of Y. R. Gaitonde Centre for AIDS Research and Education (YRG CARE; YRG-302), Chennai, India.

Study participants. The study participants consisted of two groups of individuals: seronegative female spouses of HIV-1-seropositive men (HIV-discordant couples) (HESN, $n=37$ ) and HIV-unexposed seronegative women $(\mathrm{UH}, n=35)$. Enrollment into the study required willingness to provide written informed consent for specimen collection and storage. HIV-exposed seronegative women aged between 20 and 35 years with a history of multiple unprotected sex events with an HIV-infected partner during the past 1 year were recruited into the HESN group, and HIV-negative healthy women aged between 20 and 35 years with no history of HIV exposure were recruited into the control group. Women outside the reproductive age group, women on menstruation, those with sexually transmitted infections (STIs) or other major illnesses, moribund individuals, and pregnant and lactating women were excluded from the study.

Sample collection. Collection and processing of cervical cytobrush specimens. Mucosal specimens were collected by a trained physician. At least two cytobrush specimens were obtained from each study participant. The cytobrush was inserted just within the cervical os and rotated to one $360^{\circ}$ turn. Samples contaminated visibly with blood were discarded. Immediately after sampling, the cytobrush was placed in a $15-\mathrm{ml}$ tube containing $3 \mathrm{ml}$ of RPMl 1640 medium containing $100 \mathrm{U} / \mathrm{ml}$ penicillin, $100 \mu \mathrm{g} / \mathrm{ml} \mathrm{strep-}$ tomycin, and $2.5 \mu \mathrm{g} / \mathrm{ml}$ amphotericin B and placed on ice. The specimens were transported on ice to the laboratory and processed within $3 \mathrm{~h}$ of collection. The cytobrush was gently rotated several times in the transport medium to release all the cells into the medium and then discarded. The cell suspension was centrifuged at $330 \times g$ for $10 \mathrm{~min}$, and the pellet was resuspended in complete RPMI medium containing $100 \mathrm{U} / \mathrm{ml}$ penicillin and $100 \mu \mathrm{g} / \mathrm{ml}$ streptomycin and used for flow cytometric analyses.

Collection and processing of cervicovaginal lavage. CVL samples were collected by gently washing the cervicovaginal area with $10 \mathrm{ml}$ of sterile normal saline $(\mathrm{pH} \mathrm{7.2)}$ and withdrawing the fluid using a $5-\mathrm{ml}$ syringe. Following CVL collection, samples were frozen as quickly as possible at $-80^{\circ} \mathrm{C}$. At the time of analysis, samples were thawed at room temperature and centrifuged at $10,000 \times g$ for $5 \mathrm{~min}$, and supernatants were analyzed for soluble antiviral and innate immune factors.

Quantification of total mucosal IgG, IgA, and IgM antibodies. Total $\lg G, \lg A$, and $\lg M$ antibodies were quantified in the CVL specimens using the human immunoglobulin cytokine bead array (CBA) flex set assay (BD Biosciences, San Jose, CA, USA). The Ig CBA assay was performed as per the manufacturer's instructions. Briefly, $50 \mu \mathrm{l}$ of sample, 1:2 diluted standards (1:2, 1:4, 1:8, 1:16, 1:32, 1:64, 1:128, and 1:256) and negative control (plain medium) were added to the respective tubes. About $50 \mu \mathrm{l}$ of capture bead was added to each tube and incubated for $1 \mathrm{~h}$ at room temperature. The tubes were washed with $1 \mathrm{ml}$ of wash buffer at $200 \times g$ for $5 \mathrm{~min}$, and the supernatant was removed. Phycoerythrin (PE) detection reagent $(50 \mu \mathrm{l})$ was added to the pelleted beads and incubated for $2 \mathrm{~h}$ at room temperature. The washing procedure was repeated, and the pellet was resuspended in $300 \mu \mathrm{l}$ of wash buffer and mixed well. Samples were acquired on a FACS ARIA III SORP flow cytometer (BD Biosciences), and the fluorescence correlation spectroscopy (FCS) files were analyzed using the FCAP array v3 software (BD Biosciences).

Measurement of soluble markers in CVL specimens using cytometric bead array. Proinflammatory chemokines, including MCP-1 (CCL2), RANTES (CCL5), IP-10 (CXCL10), eotaxin (CCL11), TARC (CCL17), MIP-1 $\alpha$ (CCL3), MIP-1 $\beta$ (CCL4), MIG (CXCL9), MIP-3 $\alpha$ (CCL20), ENA-78 (CXCL5), GRO $\alpha$ (CXCL1), I-TAC (CXCL11), and IL-8 (CXCL8), CD8 ${ }^{+}$T cell/NK cell cytokines and cytolytic molecules, including IL-2, IL-4, IL10 , IL-6, IL-17, TNF- $\alpha$, sFAS, sFASL, IFN- $\gamma$, granzyme A, granzyme B, perforin, and granulysin, antiviral cytokines, including IL-1 $\beta$, IL-6, IL-8, IL-10, IL-12p70, IFN- $\alpha$, IFN- $\beta$, IFN- $\lambda 1$, IL-29, IFN- $\lambda 2 / 3$, IL-28, IFN- $\gamma$, TNF- $\alpha$, 
IP-10, and GM-CSF, and Th cell cytokines, including IL-5, IL-13, IL-2, IL-6, IL-9, IL-10, IFN- $\gamma$, TNF- $\alpha$, IL-17A, IL-17F, IL-4, IL-21, and IL-22 were measured in CVL using the BioLegend LEGENDplex human multianalyte kit-based cytometric bead array (CBA) (BioLegend, CA, USA) following the manufacturer's recommendations. Briefly, beads coated with 13 specific capture antibodies were mixed. Subsequently, $50 \mu \mathrm{l}$ of the mixed capture beads, $50 \mu \mathrm{l}$ of CVL diluted 1:2 or 1:20, and $50 \mu \mathrm{l}$ of detector antibody were added and incubated for $2 \mathrm{~h}$ on a plate shaker $(250 \mathrm{rpm})$ at room temperature in the dark. Fifty microliters of streptavidin-phycoerythrin (SA-PE) detection reagent was then added to each assay tube and incubated for $30 \mathrm{~min}$ on a plate shaker (approximately $250 \mathrm{rpm}$ ) at room temperature in the dark. The samples were washed with $1 \mathrm{ml}$ of wash buffer (at $200 \times g$ ) for $5 \mathrm{~min}$. The bead pellet was resuspended in $100 \mu \mathrm{l}$ of wash buffer after discarding the supernatant. Samples were analyzed on a BD FACS ARIA III SORP flow cytometer and analyzed using the LEGENDplex data analysis software, v8.0 (BioLegend, CA, USA). Individual cytokine concentrations were indicated by their fluorescence intensities. Cytokine standards were serially diluted to facilitate the construction of calibration curves, which were necessary for determining the protein concentration of the test samples (65). The lower limit of detection of each molecule is provided in Table S3; http://www.nirt.res.in/pdf/HIV/Supplemental\%20File.pdf.

Characterization of immune cell types in cervical cytobrush specimens. Mucosal cytobrushderived cells were washed twice, and viability was evaluated by using the trypan blue dye exclusion method. The average percentage of viability was in the range of $80 \%$. The cells were stained with the following cocktails of monoclonal antibodies for enumeration of the different immune cell types (Table S1 and S2; http://www.nirt .res.in/pdf/HIV/Supplemental\%20File.pdf).

T follicular helper and Treg panel: CD3-allophycocyanin (APC) H7 (SK7, BD Bioscience), CD4-peridinin chlorophyll protein (PerCP) Cy5.5 (RPA-T4, BD Bioscience), CD8-Brilliant UltraViolet 737 (BUV737) (RPA-T8, BD Bioscience), CD45RO-BUV395 (UCHL-1, BD Bioscience), CCR7-PE-cyanine 7 (PEcy7) (G043H7, BD Bioscience), CXCR3-APC R 700 (IC6, BD Bioscience), CXCR5-Brilliant blue 515 (BB515) (RF8B2, BD Bioscience), PD-1-PE (EH12.1, BD Bioscience), CD25-APC (M-A251, BD Bioscience), and CD127-PE-CF594 (HIL.7R.M21, BD Bioscience).

NCR-expressing NK cells: CD3-APC H7 (SK7, BD Bioscience), CD16-BUV737 (3G8, BD Bioscience), CD56-APC Alexa 700 (NCAM, BioLegend), CD27-BB515 (MT271, BD Bioscience), NKG2D-PE-CF594 (ID11, BD Bioscience), NKP44-PE (p44-8, BD Bioscience), NKP46-PEcy7 (9E2, BD Bioscience), and NKP30-APC (p30-15, BD Bioscience).

KIR-expressing NK cells: CD3-APC H7 (SK7, BD Bioscience), CD16-BUV737 (3G8, BD Bioscience), CD56-BUV396 (NCAM 16.2, BD Bioscience), CD27-PEcy7 (MT271, Bio Legend), KLRG1-PE-CF94 (231A2, BioLegend), CD158a-PE (CH-L, BD Bioscience), CD158b-BB515 (CH-L, BD Bioscience), and CD158e1-APC (DX9, BD Bioscience).

The cells were stained for $20 \mathrm{~min}$ at $4^{\circ} \mathrm{C}$. About 0.5 million cells were stained for each panel. After staining, the cells were washed, fixed with BD Cytofix ( $2 \%$ paraformaldehyde), and analyzed on a FACS ARIA III SORP flow cytometer (Becton Dickinson) (58). A minimum of 300,000 total events were acquired for each panel, and data were analyzed using FlowJo software, version 10.5.4 (Tree Star Inc., Ashland, OR, USA).

Analysis of the vaginal microbiome by next-generation sequencing. The V3-V4 region of $16 \mathrm{~s}$ rRNA was sequenced using an Illumina HiSeq2500 with $2 \times 250$ cycle chemistry. The raw reads were checked for base quality, base composition, and GC content using the FastQC tool (version 0.11.8). After the quality check, preprocessing steps were used on the data. First, forward V3 and reverse V4 primer sequences were trimmed using an in-house Perl script. Properly paired paired-end reads with a Phred quality score of $>20$ were considered for V3-V4 consensus generation. The preprocessed reads were then analyzed using QIIME (66) software (version 1.9.1) to pick up operational taxonomic units (OTUs) with $97 \%$ similarity cutoff and taxonomy classification with the SILVA database as a reference (67). Various $\mathrm{R}$ packages were used for all downstream statistical analyses and figure generation. MannWhitney test was performed at the phylum, family, genus, and species levels between the two groups using the $\mathrm{R}$ package stats since the data followed a nonnormal distribution. PERMANOVA significance test was performed at the genus level using the $\mathrm{R}$ package vegan (68). Correlation analysis was performed between relative abundance at the species level, immune cell frequencies, and soluble markers by Spearman correlation using the R package psych (69).

Statistical analysis and graphical representation of the soluble factors and immunological markers. The statistical analysis and graphical representation of immunological markers were performed using the data analysis program SPICE (version 6.0) (70) and ggplot2 version 3.2 .0 (https://ggplot2.tidyverse .org/). Statistical analyses of mucosal immune cells and soluble markers were performed using GraphPad Prism, version 7.05 (GraphPad Software, Inc., CA). Values are presented as median, interquartile range, and percentage. Mann-Whitney test was used to examine the difference in frequency (\%) of different immune cell subsets and levels of soluble markers between the two groups. Correlation analysis was performed to determine the relationship between the frequency of different immune cell types and levels of mucosal soluble markers. For all analyses, differences were considered significant if the $P$ value was less than 0.05 .

\section{ACKNOWLEDGMENTS}

The present study was supported by the Department of Health Research, a Human Resource Development Young Scientist Fellowship, and The Indian Council of Medical Research, Govt. of India. The microbiome portion of the study was supported by a grant from the Swedish Research Council (2017-01330 to U. Neogi). Initial studies were supported by the United States National Institutes of Health/National Institute of Allergy and Infectious Diseases (NIH/NIAID) grant number R03-AI062420 to Suniti Solomon (deceased), University of Chennai. Vijayakumar Velu was supported in part by National Institutes of Health Grants CFAR R03, 1R01Al148377-01A1, Emory University 
CFAR grant P30 AI050409, NIH Office of Research Infrastructure Programs (ORIP) grants P51 OD011132 and U42 OD011023 (to YNPRC).

S. M. Ponnan, L. E. Hanna, and S. Swaminathan designed the conceptual framework of the study, designed experiments, and wrote the paper. S. M. Ponnan performed the experiments and analyzed the data. K. T. Thiruvengadam contributed to statistical analyses. T. R. Dinesha, S. Saravanan, S. Poongulali, and K. G. Murugavel contributed to specimen collection. C. Tellapragada, A. T. Ambikan, A. Narayanan, and U. Neogi contributed to the vaginal microbiome analysis by next-generation sequencing. S. Kathirvel, M. Mathayan, A. Rajaraman, J. Shankar, V. Velu, and B. Shacklett contributed to the review and editing of the manuscript. All authors provided valuable input throughout the study.

We declare no conflicts of interest.

\section{REFERENCES}

1. Cole AM. 2006. Innate host defense of human vaginal and cervical mucosae. Curr Top Microbiol Immunol 306:199-230. https://doi.org/10.1097/01 .lgt.0000265775.52044.2b.

2. Mestecky J, Fultz PN. 1999. Mucosal immune system of the human genital tract. J Infect Dis 179 Suppl 3:S470-S474. https://doi.org/10.1086/314806.

3. Mselle TF, Meadows SK, Eriksson M, Smith JM, Shen L, Wira CR, Sentman CL. 2007. Unique characteristics of NK cells throughout the human female reproductive tract. Clin Immunol 124:69-76. https://doi.org/10.1016/j.clim 2007.04.008

4. Wang H, Zheng X, Wei H, Tian Z, Sun R. 2012. Important role for NKp30 in synapse formation and activation of NK cells. Immunol Invest 41:367-381. https://doi.org/10.3109/08820139.2011.632799.

5. Kulkarni AG, Paranjape RS, Thakar MR. 2014. Higher expression of activating receptors on cytotoxic NK cells is associated with early control on HIV-1C multiplication. Front Immunol 5:222. https://doi.org/10.3389/fimmu.2014.00222.

6. Zhang $\mathrm{R}$, Xu J, Hong $\mathrm{K}$, Yuan L, Peng $\mathrm{H}$, Tang $\mathrm{H}$, Ma $\mathrm{P}$, Zhang $\mathrm{Y}$, Xing $\mathrm{H}$, Ruan Y, Shao Y. 2007. Increased NKG2A found in cytotoxic natural killer subset in HIV-1 patients with advanced clinical status. Aids 21:S9-S17. https://doi.org/10.1097/01.aids.0000304691.32014.19.

7. Alter G, Altfeld M. 2009. NK cells in HIV-1 infection: evidence for their role in the control of HIV-1 infection. J Intern Med 265:29-42. https://doi.org/ 10.1111/j.1365-2796.2008.02045.x.

8. Tomescu C, Abdulhaqq S, Montaner LJ. 2011. Evidence for the innate immune response as a correlate of protection in human immunodeficiency virus (HIV)-1 highly exposed seronegative subjects (HESN). Clin Exp Immunol 164:158-169. https://doi.org/10.1111/j.1365-2249.2011.04379.x.

9. van Gils MJ, Sanders RW. 2013. Broadly neutralizing antibodies against HIV-1: templates for a vaccine. Virology 435:46-56. https://doi.org/10 .1016/j.virol.2012.10.004.

10. Russell MW, Mestecky J. 2002. Humoral immune responses to microbial infections in the genital tract. Microbes Infect 4:667-677. https://doi.org/ 10.1016/s1286-4579(02)01585-x.

11. Soderlund J, Hirbod T, Smed-Sorensen A, Johansson U, Kimani J, Plummer F, Spetz AL, Andersson J, Kaul R, Broliden K. 2007. Plasma and mucosal fluid from HIV type 1-infected patients but not from HIV type 1exposed uninfected subjects prevent HIV type 1-exposed DC from infecting other target cells. AIDS Res Hum Retroviruses 23:101-106. https://doi.org/10 .1089/aid.2005.0104.

12. Nag $P$, Kim J, Sapiega V, Landay AL, Bremer JW, Laingam S, Mestecky J, Reichelderfer P, Kovacs A, Cohn J, Weiser B, Baum LL. 2004. Women with cervicovaginal antibody-dependent cell-mediated cytotoxicity have lower genital HIV-1 RNA loads. J Infect Dis 190:1970-1978. https://doi.org/10.1086/425582.

13. Xu Y, Ollerton MT, Connick E. 2019. Follicular T-cell subsets in HIV infection: recent advances in pathogenesis research. Curr Opin HIV AIDS 14: 71-76. https://doi.org/10.1097/COH.0000000000000525.

14. Locci M, Havenar-Daughton $C$, Landais $E$, Wu J, Kroenke MA, Arlehamn CL, Su LF, Cubas R, Davis MM, Sette A, Haddad EK, International AIDS Vaccine Initiative Protocol C Principal Investigators, Poignard P, Crotty S. 2013. Human circulating PD $-1^{+} \mathrm{CXCR}^{-}{ }^{-} \mathrm{CXCR} 5^{+}$memory Tfh cells are highly functional and correlate with broadly neutralizing HIV antibody responses. Immunity 39: 758-769. https://doi.org/10.1016/j.immuni.2013.08.031.

15. Shen J, Luo X, Wu Q, Huang J, Xiao G, Wang L, Yang B, Li H, Wu C. 2018. A subset of $\mathrm{CXCR}^{+} \mathrm{CD}^{+} \mathrm{T}$ cells in the germinal centers from human tonsils and lymph nodes help B cells produce immunoglobulins. Front Immunol 9:2287. https://doi.org/10.3389/fimmu.2018.02287.
16. Borgdorff H, Tsivtsivadze E, Verhelst R, Marzorati M, Jurriaans S, Ndayisaba GF, Schuren FH, van de Wijgert JHHM. 2014. Lactobacillus-dominated cervicovaginal microbiota associated with reduced HIV/STI prevalence and genital HIV viral load in African women. ISME J 8:1781-1793. https://doi.org/10.1038/ismej .2014.26.

17. Sewankambo N, Gray RH, Wawer MJ, Paxton L, McNairn D, Wabwire-Mangen F, Serwadda D, Li C, Kiwanuka N, Hillier SL, Rabe L, Gaydos CA, Quinn TC, KondeLule J. 1997. HIV-1 infection associated with abnormal vaginal flora morphology and bacterial vaginosis. Lancet 350:546-550. https://doi.org/10.1016/S0140 -6736(97)01063-5.

18. Abdool Karim SS, Passmore JS, Baxter C. 2018. The microbiome and HIV prevention strategies in women. Curr Opin HIV AIDS 13:81-87. https://doi .org/10.1097/COH.0000000000000431.

19. Low N, Chersich MF, Schmidlin K, Egger M, Francis SC, van de Wijgert JH, Hayes RJ, Baeten JM, Brown J, Delany-Moretlwe S, Kaul R, McGrath N, Morrison C, Myer L, Temmerman M, van der Straten A, Watson-Jones D, Zwahlen M, Hilber AM. 2011. Intravaginal practices, bacterial vaginosis, and HIV infection in women: individual participant data meta-analysis. PLoS Med 8:e1000416. https://doi.org/10.1371/journal.pmed.1000416.

20. Farcasanu M, Kwon DS. 2018. The influence of cervicovaginal microbiota on mucosal immunity and prophylaxis in the battle against HIV. Curr Hiv/ Aids Rep 15:30-38. https://doi.org/10.1007/s11904-018-0380-5.

21. Anahtar N, Byrne EH, Doherty KE, Bowman BA, Yamamoto HS, Soumillon M, Padavattan N, Ismail N, Moodley A, Sabatini ME, Ghebremichael MS, Nusbaum C, Huttenhower C, Virgin HW, Ndung'u T, Dong KL, Walker BD, Fichorova RN, Kwon DS. 2015. Cervicovaginal bacteria are a major modulator of host inflammatory responses in the female genital tract. Immunity 42:965-976. https://doi.org/10.1016/j.immuni.2015.04.019.

22. Gosmann C, Anahtar MN, Handley SA, Farcasanu M, Abu-Ali G, Bowman BA, Padavattan N, Desai C, Droit L, Moodley A, Dong M, Chen Y, Ismail N, Ndung'u T, Ghebremichael MS, Wesemann DR, Mitchell C, Dong KL, Huttenhower C, Walker BD, Virgin HW, Kwon DS. 2017. Lactobacillus-deficient cervicovaginal bacterial communities are associated with increased HIV acquisition in young South African women. Immunity 46:29-37. https://doi.org/10.1016/j.immuni.2016.12.013.

23. Mylvaganam $G H$, Rios $D$, Abdelaal HM, lyer $S$, Tharp $G$, Mavigner M, Hicks S, Chahroudi A, Ahmed R, Bosinger SE, Williams IR, Skinner PJ, Velu V, Amara RR. 2017. Dynamics of SIV-specific CXCR5 ${ }^{+}$CD8 T cells during chronic SIV infection. Proc Natl Acad Sci U S A 114:1976-1981. https://doi .org/10.1073/pnas.1621418114.

24. Rutishauser RL, Deguit CDT, Hiatt J, Blaeschke F, Roth TL, Wang L, Raymond KA, Starke CE, Mudd JC, Chen W, Smullin C, Matus-Nicodemos R, Hoh R, Krone M, Hecht FM, Pilcher CD, Martin JN, Koup RA, Douek DC, Brenchley JM, Sékaly R-P, Pillai SK, Marson A, Deeks SG, Mccune JM, Hunt PW. 2021. TCF-1 regulates HIV-specific CD8 ${ }^{+}$T cell expansion capacity. JCI Insight 6:e136648. https://doi.org/10.1172/jci.insight.136648.

25. Johansson SE, Rollman E, Chung AW, Center RJ, Hejdeman B, Stratov I, Hinkula J, Wahren B, Karre K, Kent SJ, Berg L. 2011. NK cell function and antibodies mediating ADCC in HIV-1-infected viremic and controller patients. Viral Immunol 24:359-368. https://doi.org/10.1089/vim.2011.0025.

26. Taborda NA, Hernandez JC, Lajoie J, Juno JA, Kimani J, Rugeles MT, Fowke KR. 2015. Short Communication: low expression of activation and inhibitory molecules on NK cells and $\mathrm{CD}^{+}{ }^{+}$T cells is associated with viral control. AIDS Res Hum Retroviruses 31:636-640. https://doi.org/10.1089/AID.2014.0325. 
27. Florez-Alvarez L, Hernandez JC, Zapata W. 2018. NK cells in HIV-1 infection: from basic science to vaccine strategies. Front Immunol 9:2290. https://doi.org/10.3389/fimmu.2018.02290.

28. Horton RE, McLaren PJ, Fowke K, Kimani J, Ball TB. 2020. Cohorts for the study of HIV-1-exposed but uninfected individuals: benefits and limitations. J Infect Dis 202 Suppl 3:S377-S381. https://doi.org/10.1086/655971.

29. Suresh P, Wanchu A. 2006. Chemokines and chemokine receptors in HIV infection: role in pathogenesis and therapeutics. J Postgrad Med 52:210-217.

30. Schellenberg JJ, Links MG, Hill JE, Dumonceaux TJ, Kimani J, Jaoko W, Wachihi C, Mungai JN, Peters GA, Tyler S, Graham M, Severini A, Fowke KR, Ball TB, Plummer FA. 2011. Molecular definition of vaginal microbiota in East African commercial sex workers. Appl Environ Microbiol 77: 4066-4074. https://doi.org/10.1128/AEM.02943-10.

31. Shacklett BL, Ferre AL, Kiniry BE. 2019. Tissue issues: mucosal T-cell responses in HIV-1 infection. Curr Opin HIV AIDS 14:100-107. https://doi .org/10.1097/COH.0000000000000530.

32. Hirbod T, Broliden K. 2007. Mucosal immune responses in the genital tract of HIV-1-exposed uninfected women. J Intern Med 262:44-58. https://doi .org/10.1111/j.1365-2796.2007.01822.x.

33. Boris S, Barbes C. 2000. Role played by lactobacilli in controlling the population of vaginal pathogens. Microbes Infect 2:543-546. https://doi.org/ 10.1016/s1286-4579(00)00313-0.

34. Shacklett BL. 2019. Mucosal immunity in HIV/SIV infection: T cells, B cells and beyond. Curr Immunol Rev 15:63-75. https://doi.org/10 .2174/1573395514666180528081204.

35. Fowke KR, Nagelkerke NJD, Kimani J, Simonsen JN, Anzala AO, Bwayo J, MacDonald KS, Ngugi EN, Plummer FA. 1996. Resistance to HIV-1 infection among persistently seronegative prostitutes in Nairobi, Kenya. Lancet 348:1347-1351. https://doi.org/10.1016/S0140-6736(95)12269-2.

36. Furci L, Lopalco L, Loverro P, Sinnone M, Tambussi G, Lazzarin A, Lusso P. 2002. Non-cytotoxic inhibition of HIV-1 infection by unstimulated $C D 8^{+} T$ lymphocytes from HIV-exposed-uninfected individuals. AIDS 16:1003-1008. https://doi.org/10.1097/00002030-200205030-00006.

37. Shacklett BL, Ferre AL. 2011. Mucosal immunity in HIV controllers: the right place at the right time. Curr Opin HIV AIDS 6:202-207. https://doi .org/10.1097/COH.0b013e3283453e2b.

38. Kaul R, Thottingal P, Kimani J, Kiama P, Waigwa CW, Bwayo JJ, Plummer FA, Rowland-Jones SL. 2003. Quantitative ex vivo analysis of functional virus-specific CD8 T lymphocytes in the blood and genital tract of HIVinfected women. AIDS 17:1139-1144. https://doi.org/10.1097/00002030 -200305230-00004.

39. Kaul R, Plummer FA, Kimani J, Dong T, Kiama P, Rostron T, Njagi E, MacDonald KS, Bwayo JJ, McMichael AJ, Rowland-Jones SL. 2000. HIV-1specific mucosal CD8 ${ }^{+}$lymphocyte responses in the cervix of HIV-1-resistant prostitutes in Nairobi. J Immunol 164:1602-1611. https://doi.org/10 .4049/jimmunol.164.3.1602.

40. Kaul R, Rowland-Jones SL, Kimani J, Dong T, Yang HB, Kiama P, Rostron T, Njagi E, Bwayo JJ, MacDonald KS, McMichael AJ, Plummer FA. 2001. Late seroconversion in HIV-resistant Nairobi prostitutes despite pre-existing HIV-specific CD8 ${ }^{+}$responses. J Clin Invest 107:341-349. https://doi.org/10 $.1172 / \mathrm{JCl} 10714$.

41. Berry JD, Rutherford J, Silverman GJ, Kaul R, Elia M, Gobuty S, Fuller R, Plummer FA, Barbas CF III. 2003. Development of functional human monoclonal single-chain variable fragment antibody against HIV-1 from human cervical B cells. Hybrid Hybridomics 22:97-108. https://doi.org/10 .1089/153685903321948021.

42. Horton RE, Ball TB, Wachichi C, Jaoko W, Rutherford WJ, McKinnon L, Kaul R, Rebbapragada A, Kimani J, Plummer FA. 2009. Cervical HIV-specific IgA in a population of commercial sex workers correlates with repeated exposure but not resistance to HIV. AIDS Res Hum Retroviruses 25:83-92. https://doi.org/10.1089/aid.2008.0207.

43. Burgener A, Boutilier J, Wachihi C, Kimani J, Carpenter M, Westmacott G, Cheng K, Ball TB, Plummer F. 2008. Identification of differentially expressed proteins in the cervical mucosa of HIV-1-resistant sex workers. J Proteome Res 7:4446-4454. https://doi.org/10.1021/pr800406r.

44. Scott-Algara D, Truong LX, Versmisse P, David A, Luong TT, Nguyen NV, Theodorou I, Barre-Sinoussi F, Pancino G. 2003. Cutting edge: increased NK cell activity in HIV-1-exposed but uninfected Vietnamese intravascular drug users. J Immunol 171:5663-5667. https://doi.org/10.4049/jimmunol.171.11.5663.

45. O'Connor GM, Holmes A, Mulcahy F, Gardiner CM. 2007. Natural killer cells from long-term non-progressor HIV patients are characterized by altered phenotype and function. Clin Immunol 124:277-283. https://doi.org/10 .1016/j.clim.2007.05.016.
46. Sivori S, Pende D, Bottino C, Marcenaro E, Pessino A, Biassoni R, Moretta L, Moretta A. 1999. NKp46 is the major triggering receptor involved in the natural cytotoxicity of fresh or cultured human NK cells. Correlation between surface density of NKp46 and natural cytotoxicity against autologous, allogeneic or xenogeneic target cells. Eur J Immunol 29:1656-1666. https://doi.org/10 .1002/(SICI)1521-4141(199905)29:05<1656::AID-IMMU1656>3.0.CO;2-1.

47. Vieillard V, Fausther-Bovendo H, Samri A, Debré $P$, French Asymptomatiques à Long Terme (ALT) ANRS-CO15 Study Group. 2010. Specific phenotypic and functional features of natural killer cells from HIV-infected long-term nonprogressors and HIV controllers. J Acquir Immune Defic Syndr 53:564-573. https://doi.org/10.1097/QAI.0b013e3181d0c5b4.

48. Romero Al, Thoren FB, Brune M, Hellstrand K. 2006. NKp46 and NKG2D receptor expression in NK cells with CD56 ${ }^{\mathrm{dim}}$ and CD56 ${ }^{\text {bright }}$ phenotype: regulation by histamine and reactive oxygen species. Br J Haematol 132: 91-98. https://doi.org/10.1111/j.1365-2141.2005.05842.x.

49. Zwolińska K, Błachowicz O, Tomczyk T, Knysz B, Gąsiorowski J, Zalewska M, Orzechowska BU, Sochocka M, Piasecki E. 2016. The effects of killer cell immunoglobulin-like receptor (KIR) genes on susceptibility to HIV-1 infection in the Polish population. Immunogenetics 68:327-337. https://doi .org/10.1007/s00251-016-0906-1.

50. Boulet S, Sharafi S, Simic N, Bruneau J, Routy JP, Tsoukas CM, Bernard NF. 2008. Increased proportion of KIR3DS1 homozygotes in HIV-exposed uninfected individuals. AIDS 22:595-599. https://doi.org/10.1097/QAD .0b013e3282f56b23.

51. Jennes W, Verheyden S, Demanet C, Adjé-Touré CA, Vuylsteke B, Nkengasong JN, Kestens L. 2006. Cutting edge: resistance to HIV-1 infection among African female sex workers is associated with inhibitory KIR in the absence of their HLA ligands. J Immunol 177:6588-6592. https://doi .org/10.4049/jimmunol.177.10.6588.

52. Rottman JB, Ganley KP, Williams K, Wu L, Mackay CR, Ringler DJ. 1997. Cellular localization of the chemokine receptor CCR5. Correlation to cellular targets of HIV-1 infection. Am J Pathol 151:1341-1351.

53. Lajoie J, Kimani M, Plummer FA, Nyamiobo F, Kaul R, Kimani J, Fowke KR. 2014. Association of sex work with reduced activation of the mucosal immune system. J Infect Dis 210:319-329. https://doi.org/10.1093/infdis/jiu023.

54. Alexander R, Mestecky J. 2007. Neutralizing antibodies in mucosal secretions: IgG or IgA? Curr HIV Res 5:588-593. https://doi.org/10.2174/ 157016207782418452.

55. Ahmad R, Sindhu ST, Toma E, Morisset R, Vincelette J, Menezes J, Ahmad A. 2001. Evidence for a correlation between antibody-dependent cellular cytotoxicity-mediating anti-HIV-1 antibodies and prognostic predictors of HIV infection. J Clin Immunol 21:227-233. https://doi.org/10.1023/A: 1011087132180.

56. Pallikkuth S, Parmigiani A, Pahwa S. 2012. The role of interleukin-21 in HIV infection. Cytokine Growth Factor Rev 23:173-180. https://doi.org/10 .1016/j.cytogfr.2012.05.004.

57. Chevalier MF, Jülg B, Pyo A, Flanders M, Ranasinghe $S$, Soghoian DZ, Kwon DS, Rychert J, Lian J, Muller MI, Cutler S, McAndrew E, Jessen $\mathrm{H}_{\text {, }}$ Pereyra F, Rosenberg ES, Altfeld M, Walker BD, Streeck H. 2011. HIV-1-specific interleukin- $21^{+} \mathrm{CD} 4^{+} \mathrm{T}$ cell responses contribute to durable viral control through the modulation of HIV-specific $\mathrm{CD}^{+} \mathrm{T}$ cell function. J Virol 85:733-741. https://doi.org/10.1128/JVI.02030-10.

58. Munusamy Ponnan S, Swaminathan S, Tiruvengadam KKKV, Cheedarla N, Nesakumar M, Kathirvel S, Goyal R, Singla N, Mukherjee J, Bergin PJTK, Gilmour J, Prasad Tripathy S, Luke HE. 2018. Induction of circulating T follicular helper cells and regulatory T cells correlating with HIV-1 gp120 variable loop antibodies by a subtype $C$ prophylactic vaccine tested in a Phase I trial in India. PLoS One 13:e0203037. https://doi.org/10.1371/ journal.pone.0203037.

59. Muema DM, Macharia GN, Olusola BA, Hassan AS, Fegan GW, Berkley JA, Urban BC, Nduati EW. 2017. Proportions of circulating follicular helper T cells are reduced and correlate with memory $B$ cells in HIV-infected children. PLoS One 12:e0175570. https://doi.org/10.1371/journal.pone.0175570.

60. Munusamy Ponnan S, Thiruvengadam K, Kathirvel S, Shankar J, Rajaraman A, Mathaiyan M, Dinesha TR, Poongulali S, Saravanan S, Murugavel KG, Swaminathan S, Tripathy SP, Neogi U, Velu V, Hanna LE. 2021. Elevated numbers of HIV-specific poly-functional $\mathrm{CD}^{+} \mathrm{T}$ cells with stem cell-like and follicular homing phenotypes in HIV-exposed seronegative individuals. Front Immunol 12:638144. https://doi.org/10.3389/fimmu.2021.638144.

61. Levy JA. 2001. The importance of the innate immune system in controlling HIV infection and disease. Trends Immunol 22:312-316. https://doi .org/10.1016/s1471-4906(01)01925-1.

62. Moriuchi H, Moriuchi M, Combadiere C, Murphy PM, Fauci AS. 1996. CD8 ${ }^{+}$ T-cell-derived soluble factor(s), but not $\beta$-chemokines RANTES, MIP- $1 \alpha$, and 
MIP-1 $\beta$, suppress HIV-1 replication in monocyte/macrophages. Proc Natl Acad Sci U S A 93:15341-15345. https://doi.org/10.1073/pnas.93.26.15341.

63. Chang TL, Klotman ME. 2004. Defensins: natural anti-HIV peptides. AIDS Rev 6:161-168.

64. Jespers V, van de Wijgert J, Cools $P$, Verhelst R, Verstraelen H, DelanyMoretlwe S, Mwaura M, Ndayisaba GF, Mandaliya K, Menten J, Hardy L, Crucitti T, for the Vaginal Biomarkers Study Group. 2015. The significance of Lactobacillus crispatus and L. vaginalis for vaginal health and the negative effect of recent sex: a cross-sectional descriptive study across groups of African women. BMC Infect Dis 15:115. https://doi.org/10.1186/s12879 -015-0825-z.

65. Bernin H, Fehling H, Marggraff C, Tannich E, Lotter H. 2016. The cytokine profile of human NKT cells and PBMCs is dependent on donor sex and stimulus. Med Microbiol Immunol 205:321-332. https://doi.org/10.1007/ s00430-016-0449-y.

66. Caporaso JG, Kuczynski J, Stombaugh J, Bittinger K, Bushman FD, Costello EK, Fierer N, Peña AG, Goodrich JK, Gordon Jl, Huttley GA, Kelley ST, Knights D,
Koenig JE, Ley RE, Lozupone CA, McDonald D, Muegge BD, Pirrung M, Reeder J, Sevinsky JR, Turnbaugh PJ, Walters WA, Widmann J, Yatsunenko T, Zaneveld J, Knight R. 2010. QIIME allows analysis of high-throughput community sequencing data. Nat Methods 7:335-336. https://doi.org/10.1038/nmeth.f.303.

67. Quast C, Pruesse E, Yilmaz P, Gerken J, Schweer T, Yarza P, Peplies J, Glöckner FO. 2013. The SILVA ribosomal RNA gene database project: improved data processing and web-based tools. Nucleic Acids Res 41: D590-D596. https://doi.org/10.1093/nar/gks1219.

68. Oksanen J, Blanchet FG, Kindt R, Legendre P, Minchin PR, O'hara R, Simpson GL, Solymos P, Stevens MHH, Wagner H. 2013. Package 'vegan'. Community ecology package, version 2. https://github.com/vegandevs/vegan.

69. Revelle W. 2015. psych: procedures for personality and psychological research. Version 1. https://personality-project.org/r/psych-manual.pdf.

70. Roederer M, Nozzi JL, Nason MC. 2011. SPICE: exploration and analysis of post-cytometric complex multivariate datasets. Cytometry A 79:167-174. https://doi.org/10.1002/cyto.a.21015. 